NBER WORKING PAPER SERIES

\title{
LABOUR MARKET REFORMS AND CHANGES IN WAGE INEQUALITY IN THE UNITED KINGDOM AND THE UNITED STATES
}

\author{
Amanda Gosling \\ Thomas Lemieux \\ Working Paper 8413 \\ http://www.nber.org/papers/w8413 \\ NATIONAL BUREAU OF ECONOMIC RESEARCH \\ 1050 Massachusetts Avenue \\ Cambridge, MA 02138 \\ August 2001
}

We would like to thank Richard Blundell, David Card, and seminar participants at UBC, UC Berkeley, UCLA and UC Santa Barbara for comments on previous drafts of the paper, and Alan Manning for help with the data. The views expressed herein are those of the authors and not necessarily those of the National Bureau of Economic Research.

(C) 2001 by Amanda Gosling and Thomas Lemieux. All rights reserved. Short sections of text, not to exceed two paragraphs, may be quoted without explicit permission provided that full credit, including $(\mathbb{C}$ notice, is given to the source. 
Labour Market Reforms and Changes in Wage Inequality in the United Kingdom and the United States

Amanda Gosling and Thomas Lemieux

NBER Working Paper No. 8413

August 2001

JEL No. J3, J5

\begin{abstract}
This paper compares trends in male and female hourly wage inequality in the United Kingdom and the United States between 1979 and 1998. Our main finding is that the extent and pattern of wage inequality became increasingly similar in the two countries during this period. We attribute this convergence to "U.S. style" reforms in the U.K. labour market. In particular, we argue that the much steeper decline in unionisation in the United Kingdom explains why inequality increased faster than in the United States. For women, we conclude that the fall and subsequent recovery in the real value of the U.S. minimum wage explains why wage inequality increased faster in the United States than in the United Kingdom during the 1980s, while the opposite happened during the 1990s. Interestingly, the introduction of the National Minimum Wage in the U.K. in 1999 also contributed to the convergence in labour market institutions and wage inequality between the two countries.
\end{abstract}

Amanda Gosling

Department of Economics

University of Essex

Wivenhoe Park, Colchester

Essex, CO4 3SQ

United Kingdom

and IFS

agosling@essex.ac.uk
Thomas Lemieux Department of Economics University of British Columbia Vancouver, BC, V6T 1Z1

Canada and NBER

tlemieux@interchange.ubc.ca 


\section{Introduction}

A large number of studies have shown that wage and earnings inequality increased sharply in the United Kingdom since the late 1970s. ${ }^{1}$ With perhaps the exception of the United States, the magnitude of the increase in wage inequality was unmatched in any other industrialised countries. ${ }^{2}$ For example, wage inequality remained relatively stable during the same period in the major continental European countries (Germany, France and Italy) while it increased at a more moderate pace in Canada and in Japan. This increase in earnings inequality was accompanied by a decrease in the earnings gap between men and women. Again the changes in the gender wage gap experienced by the United Kingdom and United States appear to be more dramatic than those found in other countries.

The divergent experiences of different countries in terms of wage inequality is a major challenge for explanations that focus on changes in the relative demand for labour across different skill classes. The most popular demand side explanation for rising wage inequality is that over the last couple of decades, technological change has been biased in favour of skilled workers. It is difficult to see, however, why this type of technical change should have been more pronounced in the United Kingdom than in countries like France and Germany.

Another possible explanation for the unique wage inequality experience of the United Kingdom is that since 1979 the institutional structures of the U.K. labour market changed dramatically. Union decline, falls in public sector employment, contracting out and competitive tendering of some public sector services resulted in changes in the way pay was formally set. Wages councils (who set minimum rates of pay in some low paying and female dominated industries) were weakened and finally abolished in 1993. Some women would have benefited from the increase in scope of sex discrimination and equal pay legislation, however. The depth and coverage of employment protection legislation was reduced, basically making it easier for firms to sack their workers. Changes to the social security and welfare system may have affected work incentives,

\footnotetext{
${ }^{1}$ See, for example, Schmitt (1996), Machin (1996) and Gosling, Machin and Meghir (2000).

${ }^{2}$ See Freeman and Katz (1996) for an overview of the inequality trends in different industrialised countries
} 
possibly increasing competitive pressure on wages at the bottom part of the distribution and changing the composition of the workforce.

The main question we ask in the paper is whether these reforms in the institutional structure of the labour market contributed to the increase in inequality in the United Kingdom? On the one hand, a quick comparison of the experiences of different European countries suggests that the answer to this question is "yes". Countries like France and Germany neither experienced the dramatic labour market reforms nor the sharp increase in wage inequality that the United Kingdom experienced over the last two decades. $^{3}$ On the other hand, it is possible that the United Kingdom would have diverged from the experience of the rest of Europe without any policy changes given the existing differences in the structure of collective bargaining and the educational and training systems. It is therefore difficult to identify the precise effect of these policy reforms through a broad comparison of the leading European economies.

Comparisons between the United Kingdom and the United States may be more fruitful, however, for at least three reasons. First, the U.S. and U.K. labour markets of the late 1990s are very similar. Wage setting where unions are present is decentralised and unions have little influence over pay in the private sector. In neither country is there a wide-ranging system of vocational education and training. Formal skill acquisition occurs at school or at university rather than on the job. ${ }^{4}$ Second, given that it is possible to think of the institutional changes in the United Kingdom as transforming its labour market in a more "U.S.-style", the United States is a natural benchmark for assessing the impact of these reforms. Third, changes in the United Kingdom (as discussed in section 2 below) were more likely to affect men, while changes in the United States (basically the decline in the real value of the U.S. minimum wage between 1979 and 1990) were more likely to affect women. A comparison of the difference in the difference in trends between men and women across the two countries may help to disentangle the effect of these institutional changes from other country-specific trends as well as trends that are

\footnotetext{
${ }^{3}$ See also Giles, Gosling, Laisney and Geib (1998) for a comparison between the United Kingdom and West Germany over the 1980 s

${ }^{4}$ This is not to say there is no on the job training in the United Kingdom and the United States but merely that training schemes which give works accredited transferable skills are rare
} 
common to both countries. The primary goal of this paper is to examine this in more detail.

The plan of the paper is the following. In Section 2, we describe the data and present descriptive statistics on the evolution of the distribution of wages in the United Kingdom and the United States during the 1980s and 1990s. In Section 3 we look directly at the role of unionisation, privatisation and the minimum wage in explaining the key differences between the evolution of wage inequality in the two countries. In Section 4, we present some qualifications and extensions to the main results of Section 3. We conclude in Section 5.

\section{Data and Descriptive Statistics}

\subsection{Data Sources}

For the United Kingdom we use a multiple dataset approach as there is no one dataset which is ideal for our purpose. More precisely, we compute the basic trends in wage inequality using the family expenditure survey (FES) for 1978 to 1996 supplemented with the autumnal labour force survey (LFS) for 1997-99 and, in few

cases, by the General Household Survey (GHS). We analyse the effect of unionisation and public sector affiliation on wage inequality by comparing the 1983 GHS and the 1998 LFS. For the United States we use data from the outgoing rotation sample of the Current Population Survey (CPS). A more detailed discussion of all the datasets we use is given in the data appendix.

\subsection{Descriptive Statistics.}

Throughout this paper, we focus on the evolution of overall measures of (hourly) wage inequality such as the standard deviation, inter-percentiles range such as the 90-10 wage ratio, and the whole density of wages. This focus is deliberate given our interest for the role of economic reforms and labour market institutions on the wage distribution. A large number of studies have stressed the importance of supply, demand, and skilled 
biased technical change in the evolution of wage differentials across education groups. ${ }^{5}$ These wage differentials only represent, however, a small fraction of total wage variability across individuals. More importantly, previous research has shown that the effect of factors such as unions and the minimum wage are best captured by modelling the whole distribution of wages rather than just focussing on the more standard wage differentials by age or education. ${ }^{6}$ For the sake of completeness, however, we also present below few education- and age-related wage differentials and a standard betweenvs. within-group variance decomposition.

Figure 1 plots the evolution of the median and the $10^{\text {th }}$ and $90^{\text {th }}$ percentile of male and female wages in the United Kingdom and the United States between 1978 and 1999 (1978 to 1998 in the United Kingdom, 1979 to 1999 in the United States), normalized to 100 in $1979 .^{7}$ The path of the medians indicates very different patterns of wage growth for different groups. In both the United Kingdom and the United States, median wages of women increase substantially relative to men. This translates into a substantial decline in the gender wage gap (at the median) as reported in Figure 3. This finding is consistent with other U.S. and U.K. studies such as Harkness (1996) and Blau (1998). Interestingly, the change in the wage gap is very similar in the two countries. Median female wages have increased from about $64 \%$ to $73 \%$ of the male median in the United Kingdom and from $64 \%$ to $75 \%$ in the United States. A second important difference is that real wages grew much faster in the United Kingdom than in the United States during this period. For instance, the median of U.S. male real wage declined between 1979 and 1998 compared to a 25 percent growth in the United Kingdom. ${ }^{8}$

Figure 1 also indicates that wage inequality increased for all four groups during this period. In all four cases, the $90^{\text {th }}$ percentile grows relative to the median. Acloser

\footnotetext{
${ }^{5}$ See, for example, Katz and Murphy (1992) for the United States, Schmitt (1996) for Britain, and Freeman and Needels (1993) and Card and Lemieux (2001) for international comparisons between the United States, the United Kingdom, and Canada.

${ }^{6}$ See DiNardo, Fortin, and Lemieux (1996).

${ }^{7}$ In Figures 1 and 2 and Table 1, we have adjusted the 1997 and 1998 data to ensure there is no discontinuity between the 1996 FES and the 1997 LFS due to differences in the survey instruments. See the data appendix for more details.

${ }^{8}$ A similar difference has been noticed in other comparisons between the United States and France (Card, Kramarz and Lemieux, 1999) or Germany (Beaudry and Green, 2000). Beaudry and Green suggest that differences in the accumulation of physical capital per capita, which grew much faster in Germany than in the United States during this period, may help explain this important gap.
} 
examination of the figure indicates, however, that most of the growth in inequality actually occurred during 1980s, while inequality remained more stable in the 1990s. Figure 1 also shows that inequality increased more for some groups than some others. For example, the increase in wage inequality over the whole sample period is much less pronounced for men in the United States than in the United Kingdom. These trends in wage inequality are more readily seen in Figure 2 that reports the evolution of both the 90-10 differential and the standard deviation of $\log$ wages. Both the standard deviation and the 90-10 differential show the same steep increase in wage inequality in the 1980s, followed by more modest growth in the 1990s.

Beyond these broad similarities in the pattern and growth of wage inequality in the United Kingdom and the United States, Figures 1 and 2 also illustrate some important differences between the two countries. The slowdown of inequality growth in the 1990s is much more marked in the United States, and in particular for women. Over the 1980s the increase in the both the 90-10 differential and the standard deviation of female wage is larger in the United States than in the United Kingdom. In the 1990s the opposite is true. In addition, the level of wage inequality, as measured by the standard deviation and the 90-10 differential, is systematically lower for men than women in the United Kingdom, while the opposite is true in the United States. Furthermore, the figure shows that while wage inequality grows faster for men than for women in the United Kingdom, the opposite is true in the United States.

One way of summarising the data is to say that the extent of wage inequality has converged in the two countries over the last 20 years. While there were important differences in the level and pattern of wage inequality across gender and countries in the late 1970s, much of these differences have vanished by the late 1990s. Male wage inequality in the United Kingdom has caught up to the level of female wage inequality and is moving closer to the level of male inequality in the United States.

The convergence in wage inequality in the two countries is shown more explicitly in Table 1 which reports several measures of inequality for men and women in 1979, 1989, and 1998. ${ }^{9}$ For example, the 0.084 U.S.-U.K. difference in the male standard

\footnotetext{
${ }^{9}$ The statistics reported for 1979 and 1989 in the United Kingdom are averages for 1978 to 1980, and 1988 to 1990 , respectively.
} 
deviation in 1979 (0.460 in the United States vs. 0.376 in the United Kingdom) declines to 0.063 in 1989 and 0.028 in 1998 , which is only a third of the original difference. By contrast, the U.S.-U.K. difference in the female standard deviation is relatively modest throughout the 1980s and 1990s.

As is well known, the standard deviation and the 90-10 wage differential are two standard measures of wage inequality that capture different features of the wage distribution. For example, changes in the wage distribution above the $90^{\text {th }}$ percentile affect the standard deviation but not the 90-10 differential. A more general way of looking at what happens where in the distribution of wages is to plot the whole distribution of wages. In this light Figure 4 shows kernel density estimates of the distribution of $(\log )$ wages for men and women in the United Kingdom in 1979, 1989, and 1998. For both men and women, there is clear visual evidence that the wage distribution becomes increasingly unequal over time. In both cases, the density in the middle of the distribution declines while it increases in the tails.

Figure 4 also shows that the female wage distribution is positively skewed in all years. The distribution of male wages is also skewed, but to a much smaller extent. This skewness in the U.K wage distribution is also illustrated in Table 1 which shows that the 90-50 wage differential is systematically larger than the 50-10 differential. The situation is quite different in the United States. Figure 5a shows that the male wage distribution in 1979 was in fact negatively skewed, though it becomes much more symmetric over time. As in the case in the United Kingdom, there is clear evidence of an overall increase in wage inequality. The density of wages declines in the middle of the distribution and increases in the tails.

These qualitative changes in the shape of the U.S. male distribution are confirmed in Table 1 which shows that the 50-10 wage differential is substantially larger than the 90-50 differential in 1979. By 1998, however, the distribution is more or less symmetric since the 90-50 and 50-10 differentials are comparable. By contrast, the U.S. female wage distribution, shown in Figure 5b, is positively skewed, and the 90-50 wage differential is systematically larger than the 50-10 differential. The increase in overall inequality is perhaps clearer for U.S. women than for other groups because average wages are relatively stable over time. As a result, Figure $5 b$ clearly shows that the 
density declines in the middle of the distribution but increases in the tails. The same pattern is not as clearly seen for other groups because average wages shift substantially over time.

In summary, the different pieces of evidence all suggest that the U.K. wage distribution is becoming increasingly similar to the U.S. wage distribution. This is particularly clear in the case of men for which the shape of the wage distribution (skewness) and the extent of inequality (standard deviation and 90-10 differential) were quite different in 1979. Most of these differences had vanished by 1998. There is also a convergence between the U.K. and U.S. female wage distributions, though differences were perhaps more subtle in 1979 than in the case of men. The 1979 density in the United Kingdom has a well-defined single peak while there is a relatively flat section in the middle of the U.S. distribution. By contrast, the shapes of the U.K. and U.S. distribution look much more similar in 1998.

Since real wages were initially lower but grew faster in the United Kingdom than in the United States, both the level and the distribution of wages have converged. One simple way of representing this overall wage convergence between the two countries is to show to which percentile of the U.K. real wage distribution corresponds a given percentile of the U.S. real wage distribution. ${ }^{10}$ Figure 6a illustrates these "Q-Q" plots for men in 1979, 1989, and 1998. ${ }^{11}$ The figure shows, for example, that the median wage for U.S. men is equivalent to the $90^{\text {th }}$ percentile of the U.K wage distribution in 1979 . The percentile of the U.K. wage distribution corresponding to the U.S. median drops to the $70^{\text {th }}$ in 1989 and to the $60^{\text {th }}$ in 1998 as U.K. real wages keep catching up to U.S. levels. Overall, the relationship between U.K. and U.S. wage percentiles gets increasingly close to a 45 degrees line, which illustrates dramatically the convergence

\footnotetext{
${ }^{10}$ We use the OECD purchasing power parity exchange rates for 1996 ( 0.65 pounds per dollar) to convert the U.K. real wages (in 1996 pounds) into 1996 U.S. dollars.

${ }^{11}$ To make the figure more informative, we have normalized the scales using the inverse of the cumulative normal distribution. The reason for doing so is that if the distribution of $(\log )$ wages is approximately normal in both countries, U.K. percentiles (in the normalized scale) are a linear function of U.S. percentiles and the variance of U.K. wages is lower if this slope is smaller than one. The same interpretation of the "un-normalized" Q-Q plots only applies if the (log) wage distributions are approximately uniform. It is clear from Figures 4 and 5, however, that the empirical wage distributions are much closer to a normal than to a uniform distribution.
} 
between the distribution of real wages in the two countries. The same basic pattern of wage convergence is also observed for women in Figure $6 \mathrm{~b}$.

\subsection{Wage Dispersion Between and Within Groups of Workers}

Our focus on overall wage inequality is different from the bulk of the literature that has mostly focused on the evolution of wage differential between different "skill groups" such as college and high school workers. For the sake of comparability with this literature, we present a set of standard age and education wage differentials for the United Kingdom and the United States in Table 2. These differentials are computed by running regression of log wages on a set of age and education dummies. We use the same set of age dummies for the age groups 23-29, 30-39, 40-49, and 50-59 in both countries. For the United States, we use a set of five education categories: high school dropouts, high school graduates, some college, college graduates and college post-graduates.

Unfortunately, the information on educational achievement is quite limited in the FES samples. The wage differential reported in Table 2 for 1979 and 1989 are thus computed using the General Household Survey (GHS) while the LFS is used for $1998 .^{12}$ To get large enough samples, we pool the 1978, 1979 and 1980 GHS to compute wage differentials for 1979, and the 1988, 1989 and 1990 GHS for 1989. We construct six education categories for the GHS and the LFS: no qualification, some vocational qualifications (low, middle and high), A-O level qualifications and university graduates. We also decompose the variance of wages into a between- and within-group component by running wage regressions on a rich set of individual characteristics. ${ }^{13}$

With few exceptions, the different measures of wage dispersion reported in Table 2 show trends similar to those reported earlier for overall wage inequality. For instance,

\footnotetext{
${ }^{12}$ As discussed in the Data Appendix, the GHS is not an ideal data sources because weekly hours of work are not measured consistently over time. Despite this shortcoming, however, the FES and the GHS show quite similar increases in the standard deviation of log hourly wages during the 1980s. Table 1 indicates that between 1979 and 1989, the standard deviation computed using the FES increased by 0.088 and 0.077 for men and women, respectively. Comparable numbers from the GHS are 0.081 and 0.083 , respectively.

${ }^{13}$ The variables used in log wage regression are a set of regional dummies (ten regions and London in the United Kingdom, nine regions and SMSA status in the United States), a dummy variable for marital status, and a set of education dummies (seven in the United Kingdom, five in the United States) fully interacted with a fourth degree polynomial in age. The U.S. models also include dummy variables for race and veteran status.
} 
there is generally a more marked slowdown in inequality growth in the United States than in the United Kingdom during the 1990s. Another difference between the two countries is that the wage gap between college (university) and high school (A-O level) educated workers has expanded faster in the United States than in the United Kingdom. ${ }^{14}$ This explains why a larger fraction of the growth in inequality comes from the between-group component in the United States.

A related point is that, in absolute terms, the growth in between-group inequality is more or less similar for men and women in the two countries. The differential evolution in inequality for men and women highlighted previously is almost entirely driven by changes in within-group inequality which increases more for men than women in the United Kingdom, while the opposite is true in the United States. While explanations for changes in the structure of wages based on the supply and demand for different skill groups have natural implications for between-group inequality, they have little testable implications for within-group inequality. Therefore, it is unlikely that these explanations could account for the differential evolution of inequality among men and women in the two countries. This provides an additional motivation for focusing on the role of labour market reforms and institutional changes in the remainder of this paper.

\section{Effect of Reforms and Institutions on the Distribution of Wages}

We have just shown that the structure of wages appears to have converged for the two countries. In the introduction we highlighted the fact that institutional structures have also converged. On the one hand, U.K. men were relatively better "protected from inequality" than their U.S. counterparts in the late 1970s because of the strength of U.K. trade unions. On the other hand, U.K. women were not as well protected from inequality because of the lack of a comprehensive national minimum wage policy. These two observations may potentially explain the difference in the evolution of male and female wage inequality in the two countries between 1979 and 1998. We now examine this view in more detail.

\subsection{Minimum Wages}

${ }^{14}$ Card and Lemieux (2001) report a similar finding. 
The minimum wage has been closely linked to the expansion in wage inequality in the United States during the 1980s. As shown in Figure 7, the real value of the minimum wage fell sharply between 1979 and 1989 before recovering somewhat in the 1990s. ${ }^{15}$ DiNardo, Fortin, and Lemieux (1996) and Lee (1999) argue that the decline in real value of the U.S. minimum wage accounts for most of the increase in wage inequality in the lower end of the distribution during the 1980s. This is especially the case for women who are more likely than men to earn wages at or close to the minimum wage.

The United Kingdom, on the other hand, had no national minimum wage until 1999. Instead workers in some low-paying industries (for example clothing, retail and catering) were covered by institutions called wage councils which set industry level minima. These were reformed in 1986 and abolished in 1993 (in Great Britain). In 1993 some 2.5 million workers were covered. The key distinction between the United States and the United Kingdom in 1979 was in the heterogeneity of coverage. In the United Kingdom, some low-paid workers had no protection at all, and the levels of protection varied not only across industries but also (until 1986) within industries. In terms of changes over time, the United States experienced a steady fall in the minimum wage over the 1980s affecting all workers in the same way unlike the United Kingdom where there was no such change. In the 1990s the U.S. minimum rose in real and nominal terms and we should expect this to halt the growth in wage inequality. We should also expect to see a small increase in wage inequality for U.K. women after 1993.

The trends, reported in Figure 1 and Table 1, are broadly consistent with the findings of the previous literature. During the 1980s, the 50-10 wage differential expanded faster for U.S. women than for any other groups. The visual effect of the minimum wage can also be seen in Figure $5 \mathrm{~b}$ where the lower end of the female wage distribution is distorted by the (relatively) high value of the minimum wage. The shape of the wage distribution evolves towards a more regular bell-shaped distribution in 1989 as the minimum wage becomes increasingly less binding. The lower end of the distribution becomes slightly more compressed in the 1990s as the minimum wage starts

\footnotetext{
15 Between 1979 and 1981, the nominal minimum wage increased from $\$ 2.9$ to $\$ 3.35$ but the CPI increased even faster. The real value of the minimum wage fell sharply as the nominal value of the minimum wage remained at \$3.35 until April 1990 when it was raised to \$3.80, and to \$4.25 in April 1991. Inflation
} 
increasing again. By contrast, there is much less evidence of a visual effect of the minimum wage for men. ${ }^{16}$

Both Figure 1 and Table 1 also show that the 50-10 wage differential started narrowing in the United States during the 1990s as the real value of the minimum wage started increasing again. The fact that the 50-10 wage differential expands in 1980s but narrows again in the 1990s in the United States, while it keeps expanding in the United Kingdom, illustrates the important role of the minimum wage for wage inequality. Figures 1 and 2 also show a small acceleration of the increase in female wage inequality in the United Kingdom in the mid 1990s.

Broader measures of wage inequality such as the standard deviation and the 90-10 differential illustrate the same qualitative story for women. Both of these measures expand faster in the United States than in the United Kingdom during the 1980s, while the opposite happens in the 1990s (Table 1). The decline and subsequent recovery of the real value of the minimum wage in the United States is a natural explanation for this set of facts.

We explore this explanation in more detail in Figure 8 which shows the evolution of the U.K.-U.S. difference in the variance of female wages along with a measure of the "pressure" that the U.S. minimum wage exerts on the U.S. variance of wages. ${ }^{17}$ This measure of minimum wage pressure is computed using a "tail pasting" procedure suggested by DiNardo, Fortin, and Lemieux (1996). The procedure relies on the assumption that if the real minimum wage had remained at its highest (1979) value throughout the 1980s and 1990s, the distribution of wages at or below the 1979 minimum wage would have remained the same as in 1979. Under this assumption, a counterfactual distribution can be computed in year $t$ by replacing the part of the year $t$ wage distribution at our below the 1979 minimum wage by the corresponding section of the 1979 wage distribution. Our measure of minimum wage pressure is the difference between this

eroded once again the value of the real minimum wage until October 1996 and September 1997 when the minimum wage was increased successively to $\$ 4.75$ and $\$ 5.15$, respectively.

${ }^{16}$ DiNardo, Fortin and Lemieux (1996) find a clearer impact of the minimum wage for all men age 16 to 64. We miss a substantial fraction of minimum wage workers in this paper by focusing only on workers above the age of 22 .

${ }^{17}$ Because of smaller sample sizes, we smooth the U.K. variance of wages using a three-year moving average before computing the U.K.-U.S. difference in the variance of wages. 
counterfactual and the actual variance of wages in each year, normalized to zero in 1979..$^{18}$

Figure 8 shows that our measure of minimum wage pressure more or less follows the U-shaped pattern of the real minimum wage illustrated in Figure 7 . While the difference between the U.K. and the U.S. variances follows a more irregular pattern, the series is also U-shaped as inequality grows slower in the United Kingdom than in the United States in the 1980s, while the opposite happens in the 1990s.

Interestingly, a simple OLS regression indicates that the minimum wage pressure variable has a positive and significant effect on the U.K.-U.S. gap in the variance of female wages. The estimated coefficient is 0.78 with a standard error of 0.20 , which means we cannot reject the null hypothesis that a given change in the variance of U.S. wages induced by a change in the minimum wage has a one-to-one impact on the U.KU.S. gap in the variance of wages. This finding is robust to the inclusion of a linear time trend which is not statistically significant. However, only about half of the variation in the variance gap can be explained by the minimum wage pressure variable (the R-squared of the regression is 0.46). The results nevertheless confirm that the U.S. minimum wage goes a long way towards explaining the relative evolution of female wage inequality in the two countries.

One interesting conjecture is that the introduction of the U.K. minimum wage in 1999 may have contributed to the U.K.-U.S. convergence in wage inequality and labour market regulations for women in the same way U.K. de-unionisation potentially did for men. Figure 2 shows that, though the gap has declined over time, wage inequality was still larger for U.K. women than U.K. men in 1998. This raises the obvious question of whether the introduction of the National Minimum Wage in 1999 was enough to "tilt the balance" in the U.S. direction by pushing U.K. female wage inequality below U.K. male wage inequality.

\footnotetext{
${ }^{18}$ We compute the counterfactual distribution by replacing all year $t$ observations at or below the 1979 minimum wage by corresponding 1979 observations, and re-weight observations so that the total number of (weighted) observations remains unchanged. For the procedure to be valid, we need to assume that there are no employment or spillover effects due to the minimum wage. DiNardo, Fortin, and Lemieux (1996) and Lee (1999) argue that, if anything, these assumptions tend to understate the true impact of the minimum wage on the distribution of wages.
} 
In Table 3, we perform some simple simulations using the 1998 LFS to gauge the potential effect of the minimum wage on male and female inequality in the United Kingdom. In these simulations, we assume that only a fraction of workers earnings less than the 1999 minimum wage of 3.6 pounds would have earned at least 3.6 pounds if this minimum wage had prevailed in 1998. As is well known, because of imperfect coverage, lack of compliance, or measurement error in self-reported wages, a substantial fraction of workers report wages that are below the minimum wage. On the basis of recent estimates provided by the Office of National Statistics (ONS), we assume that two thirds of workers who report wages below 3.6 pounds in 1998 would have earned at least 3.6 pounds if the minimum wage had prevailed in that year. ${ }^{19}$ We carry the simulations by randomly picking two thirds of workers earning less than 3.6 pounds and increasing their wages to 3.6 , while leaving wages of other sub-minimum wage workers unchanged. ${ }^{20}$

The results of these simulations are reported in column 2 of Table 3 . The table shows the $5^{\text {th }}$ and $10^{\text {th }}$ percentiles of the wage distribution, as well as the 90-10 differential and the standard deviation of log wages. The simulated impact of the minimum wage is the difference between the simulated value of these wage statistics in column 2 and their actual value for 1998 in column 1. The results for men in Panel A indicate that the minimum wage has no effect on either the $5^{\text {th }}$ or the $10^{\text {th }}$ percentile of the wage distribution. This simply reflects the fact that less than five percent of men earned less than 3.6 pounds in 1998 (the $5^{\text {th }}$ percentile is 3.84). Nevertheless, we estimate that introducing a 3.6 pounds minimum wage would have decreased the standard deviation of log wages by 0.014 .

As expected, the minimum wage has a much larger effect for women. Panel B of Table 2 shows that introducing a 3.6 pounds minimum wage would have raised both the $5^{\text {th }}$ and the $10^{\text {th }}$ percentile to 3.6. This effect is strong enough to lower the 90-10 differential by 0.054 and the standard deviation by 0.030 . As a result, both the 90-10 differential and the standard deviation become lower for women than for men.

\footnotetext{
${ }^{19}$ Using data from the New Earnings Survey (NES) and improved wage data from the LFS, the ONS estimates that, relative to 1998, the fraction of workers age 22 and more earning less than 3.6 pounds declined by 4.6 percentage points in 1999 and 5.7 percentage points in early 2000. The latter figure represents about two thirds of the fraction of workers we observed below 3.6 pounds in 1998 .
} 
With the recent release of the 1999 LFS data, it is also possible to see how the actual distribution of wages has evolved with the introduction of the minimum wage. Column 3 shows the various wage statistics for 1999 using the same average hourly earnings measure as in $1998 .^{21}$ Since March 1999, however, the LFS has started asking directly the hourly rate of pay of hourly rated workers, just like in the U.S. CPS. In column 4, the direct information on hourly wages is used for all workers who answer this question. In both the United Kingdom and the United States, the effect of the minimum wage on direct measures of hourly wage rates is much clearer because of the measurement error in average hourly earnings measures. ${ }^{22}$

One difficulty with a straight comparison of the wage distribution between 1999 and 1998 is that factors other than the minimum wage may have also changed the wage distribution during this period. For instance, male wage inequality remains more or less constant during this period, suggesting that other sources of increasing wage inequality may be offsetting the impact of the new minimum wage. If these other factors have the same impact for men and women, however, a more accurate measure of minimum wage impacts is obtained by contrasting the evolution of wage inequality for men relative to women.

The male-female difference in wage inequality are shown in Panel C. In 1998, there was little difference in wage inequality between men and women (column 1). According to the simulation reported in column 2, wage inequality should now be larger for men than women with the introduction of the national minimum wage. Depending on which wage measure is used for 1999, the male-female difference in inequality is either slightly smaller (column 3) of larger (column 4) than predicted by the simulation.

Overall, these results confirm our conjecture that the introduction of the national minimum wage in 1999 was enough to pull U.K. female wage inequality below U.K.

\footnotetext{
${ }^{20}$ As discussed by DiNardo, Fortin, and Lemieux (1996), we probably understate the impact of the minimum wage in these simulations by ignoring possible spillover or disemployment effects. Lee (1999) confirms that minimum wage impacts become indeed larger when these factors are taken into account.

${ }^{21}$ Workers are asked to report earnings for their usual pay period (weekly, bi-weekly, monthly, etc.) in the LFS. Wage rates are then computed by dividing earnings by hours over the relevant period.

${ }^{22}$ In the 1999 LFS, only $0.4 \%$ of workers earn exactly 3.6 pounds per hour when average hourly earnings are used. This proportion jumps to $2.5 \%$ when direct measures of the hourly wage rate are used whenever available.
} 
male wage inequality. The new minimum wage has, therefore, contributed to the convergence in wage distribution between the United Kingdom and the United States

\subsection{Unionisation}

The weakening of the power of U.K. unions throughout the 1980s and 1990s can be illustrated by the strong decline in the rate of union membership. Figure 9 shows that the rate of union membership declined by more than 20 percentage points between 1979 and 1998. Though the decline is slightly more pronounced between 1979 and 1989, the rate of union membership keeps declining up to the late 1990s. By contrast, the decline in the U.S. rate of union membership is more modest and concentrated in the 1979 to 1984 period. As a result, the difference in the rate of union membership between the two countries shrinks from about 28 percentage points in 1979 to about 16 percentage points in 1998. This change has affected men more than women. Over the 1990s, for example, male union density fell from $44 \%$ in 1989 to $31 \%$ in 1999 , while female union density fell from $33 \%$ to $29 \%$ over the same period. ${ }^{23}$

Starting with Freeman (1980, 1982) and Metcalf (1977, 1982), several studies have clearly established that unions tend to reduce wage inequality among US and UK males. Studies have also established that de-unionisation has contributed to the increase in wage inequality in both the United States and the United Kingdom during the 1980s. ${ }^{24}$ By contrast, the existing evidence suggests that union have relatively little effect on wage inequality among women (Lemieux, 1993), and that de-unionisation did not play a significant role in the increase in female wage inequality in the United States (DiNardo, Fortin, and Lemieux, 1996).

What explains this difference in the impact of unions for men and women? As is well known, unions have typically two offsetting effects on wage inequality. On the one hand, wage compression policies of unions result in lower inequality within the union than non-union sector. On the other hand, since unions raise the average wage in the union relative to the non-union sector, they may well increase the inequality between

\footnotetext{
${ }^{23}$ Source: DTI

${ }^{24}$ See Freeman (1993), Card (1992), and DiNardo, Fortin and Lemieux (1996) for the United States, and Gosling and Machin (1995) for the United Kingdom. Because of difference in estimation methods and
} 
union and non-union workers. Lemieux (1993) argues that this latter effect is particularly important for women for which unionisation is concentrated in highly skilled public sector jobs such as teachers, nurses, etc. In other words, unions tend to increase wages for women who would have earned relatively high wages even in the absence of unions, thereby worsening this source of wage inequality. This between-group effect is not as important for union men who are not particularly skilled relative to non-union men.

We first illustrate the effect of unions on wage inequality by performing simple variance decompositions. At this stage, we ignore altogether differences in the skill composition of the union and non-union workforces and basically attribute to union wage policies the differences in the mean and variance of wages between the union and nonunion sector.

We focus on the effect of union on the wages of union members relative to nonunion members. Ideally, we would divide workers on the basis of whether their wages and working conditions are covered by a union contact. The U.K. data, however, are not available for this analysis. Though the distinction between coverage and membership is relatively minor in the United States where a very large fraction of covered workers are union members, the distinction is more problematic in the United Kingdom. As a result, we may well understate the effect of unions on wage inequality by focusing on union members since a substantial fraction of non members are covered by union agreements.

As explained in the data appendix, we only have data to compute the effect of deunionisation on wage inequality for the two countries for the period starting in 1983. Given our main goal of explaining the relative evolution of U.K. and U.S. wage inequality, we do not miss any important developments by focusing on the 1983-98 period as it is then where the time path of union membership diverges between the two countries (see Figure 9).

The variance of wages can be decomposed as follows:

$$
\operatorname{Var}(w)=\hat{U} \cdot \operatorname{Var}(w \mid U=1)+(1-\hat{U}) \cdot \operatorname{Var}(w \mid U=0)+\hat{U} \cdot(1-\hat{U}) \cdot \ddot{A},
$$

data, however, it is difficult to explicitly compare the quantitative impact of de-unionisation on wage inequality in the two countries. 
where $\hat{\mathrm{U}}$ is the unionisation rate (actual or simulated), and $\ddot{\mathrm{A}}$ is the difference in mean wages between the union and non-union sectors $(\mathrm{E}(\mathrm{w} \mid \mathrm{U}=1)-\mathrm{E}(\mathrm{w} \mid \mathrm{U}=0))$. The first two terms in equation (1) represent the within-group variance; the last term represents the between-group variance.

Table 4 shows the different elements of this variance decomposition. Consider first the case of men in panel A. Rows 1 and 2 report the variance of $(\log )$ wages in the union and non-union sectors, respectively. As expected, the variance of log wages is much smaller in the union than the non-union sector in both countries in both years. Interestingly, the variance in the union sector is almost identical in the United Kingdom and in the United States in the two years. By contrast, the variance in the non-union is much larger in the United States (0.296) than in the United Kingdom (0.219) in 1983. By 1998, however, the variances are very similar in the two countries. Consistent with previous research, row 3 shows that the difference in mean wages between the union and nonunion sectors (union wage gap) is always positive but smaller in the United Kingdom than the United States. ${ }^{25}$

The same basic wage patterns can be seen in Appendix Figure 1, which shows kernel density estimates of wages among union and non-union men. The figure shows that, in both countries, the wage distribution is more compressed and has a higher mean in the union than in the nonunion sectors. The U.K. and U.S. wage distributions look remarkably similar in 1998. In 1983, however, there is noticeably less difference between the union and nonunion distributions in the United Kingdom than the United States. The basic patterns that emerge from this figure are, therefore, consistent with patterns found for the variances in Table 4.

Row 4 shows that the unionisation rate among men decreased much faster (by 25 percentage points) in the United Kingdom than in the United States (10 percentage point decline). Row 5 reproduces the earlier finding that wage inequality --measured by the

\footnotetext{
${ }^{25}$ For example, Stewart (1983) report standard OLS estimates of the union wage gap of about 7 percent in the United Kingdom, compared to a range of 10 to 15 percent (Lewis, 1986) in the United States. These estimates are not strictly comparable to those reported in Table 2 for which differences in characteristics between the two sectors are not controlled. In Appendix Table 1, we report OLS estimates of the union wage gap in 1983 and 1998 for the two countries. For men, our union wage gap estimates range from 0.06 to 0.12 in the United Kingdom, and from 0.12 to 0.17 in the United Kingdom, which is similar to the estimates reported by Stewart and Lewis.
} 
variance of $\log$ wages in this case-increases faster in the United Kingdom than in the United States.

In row 6, we compute the variance of wages that would have prevailed in 1983 and 1998 if the unionisation rate had remained stable at its 1983 level using the usual variance decomposition in equation (1) above. Column 3 of row 6 shows that the variance of U.K. wages would have increased by 0.052 if the rate of unionisation had remained stable, compared to an actual increase of 0.079 . In other words, deunionisation contributed to a 0.027 increase in the variance of wages (row 7) which represents 34 percent of the total change. In the United States, de-unionisation accounts for 0.012 , or 41 percent, of the 0.028 increase in the variance of wages between 1983 and 1998.

The results reported in panel $\mathrm{B}$ confirm the finding of the previous literature that unions have little effect on the wage inequality for women. Relative to men, there is a modest difference between the variance in the union and the nonunion sector (rows 1 and 2). Furthermore, the raw union wage gap (row 3) is much larger than for men, suggesting a much larger "between-group" effect which tends to increase inequality. ${ }^{26}$ Finally, the decline in the rate of unionisation is less than half as large for women as for men (row 4). For all these reasons, de-unionisation accounts for less than 5 percent of the increase in the variance of wages in either country.

In Tables 5 and 6, we provide further evidence on the effect of unions on male wage inequality. In Table 5, we use equation (1) to compute the variance of wages under various counterfactual assumptions about the rate of unionisation. Column 1 reports the actual variances in the two countries. As discussed earlier, the gap in male wage inequality between the two countries shrinks between 1983 and 1998: the gap in the variance declines from 0.084 to 0.033 . Columns 2 and 3 show that a large portion of this declining gap can be attributed to differences in the unionisation rate between the two countries. For example, column 2 shows that the U.K.-U.S. difference in the variance

\footnotetext{
${ }^{26}$ Appendix Table 1 shows that, for women, the OLS estimates of the union wage gap are systematically smaller than the unadjusted gaps reported in Table 2, indicating that, even in the absence of unions, unionized women would have earned more than non-unionized women because of their human capital or job characteristics. This confirms that finding in the literature that unions increase the between-group variance by pushing up the wages of women who would have earned relatively high wages even in the absence of unions.
} 
would have been three times smaller if the U.S. unionisation rate had been as high as in the United Kingdom. Overall, this table provides additional evidence that the convergence in the unionisation rate contributed to the convergence in male wage inequality.

One concern with the counterfactual exercises of Table 4 and 5 is that they may just be reflecting differences in the composition of the union and non union workforces, as opposed to true "causal" effects of unionisation on wage inequality. For example, the variance of wages may be smaller in the union sector because the workforce is more homogenous than in the nonunion sector, and not because unions truly compress the wage structure.

DiNardo, Lemieux, and Fortin (1996) suggest a simple "re-weighting" method for controlling for differences in observable characteristics when modelling the distribution of wages. The basic dea is to estimate the probability that a worker with given set of observed characteristics $x$ is unionized in both 1983 and 1998. Call these probabilities $\mathrm{P}_{83}(x)$ and $\mathrm{P}_{98}(x)$, respectively. The counterfactual distribution of wages that would have prevailed in 1998 if the probability of unionisation (as a function of $x$ ) had remained as in 1983 is obtained by "re-weighting" observations for union and nonunion workers by $\mathrm{P}_{83}(x) / \mathrm{P}_{98}(x)$ and $\left(1-\mathrm{P}_{83}(x)\right) /\left(1-\mathrm{P}_{98}(x)\right)$, respectively. ${ }^{27}$ Summary measures of inequality such as the variance or the 90-10 wage differential can then be computed from this counterfactual distribution. If it is the case that union workers have the same unobserved characteristics as non union workers conditional on observables, then these differences between the actual and counterfactual distributions can be taken as measuring the causal effect of unions on wages. ${ }^{28}$

Table 6 illustrates the effect of unions on male wage inequality obtained using this reweighting procedure. Columns 1 and 2 show the unionisation rate and several measures of inequality that prevailed in 1983 and 1998, respectively. The same numbers are recomputed from the 1998 reweighted sample in column 3. Note that the counterfactual unionisation rate in 1998 is lower than in 1983. This indicates that the

\footnotetext{
${ }^{27}$ We estimate these probabilities using a logit model. The explanatory variables used are a quartic function of age fully interacted with education categories, and sets of dummy variables for marital status, regions (ten regions and London in the United Kingdom, nine regions and SMSA status in the United States), and dummies for race and veteran status in the United States.
} 
distribution of characteristics (the $x$ 's) have changed in a way that reduces the probability of being unionized.

The counterfactual measures of wage inequality in column 3 are systematically lower than in the unadjusted 1998 distribution of column 2, indicating that deunionisation could have contributed to the rise in wage inequality even when composition effects are adjusted for. In the United Kingdom, the resulting effect of de-unionisation on the variance of wages shown in column $4(0.025)$ is very similar to the "naï ve" estimate reported in Table 4 (0.027). The estimates reported in Table 6 indicate that the faster decline in unionisation in the United Kingdom can account for about a third of the U.K.U.S. convergence in male wage inequality between the two countries over the 1983-1998 period.

\subsection{Other institutional change- Privatisation}

Another reform affecting the UK labour market was the reduction of the role of the public sector as an employer. These changes occurred directly through the privatisations of the late 1980s and 1990s and indirectly through the contracting out of public sector services. Public sector employment fell from 7.45 million in 1979 to 5.23 million in 1995. In addition competitive tendering of services forced convergence of wages between the public and private sectors for some groups of workers. By contrast, existing research indicates that the fraction of workers in the public sector has remained more or less constant in the United States during this period. ${ }^{29}$

Wages in the public sector are more compressed in both the United Kingdom and the United States. Both the wage premia associated with observed skill and the wage distribution within skill groups are smaller in the public sector. ${ }^{30}$ It seems plausible, therefore, that the decline in the role of the public sector as an employer would have had an significant effect on the wage distribution in the United Kingdom especially for men. The decline is not as steep for women who are more heavily concentrated in sectors such

\footnotetext{
28 This assumption is discussed in mo re detail below

29 See Poterba and Rueban (1994).

${ }^{30}$ For the United Kingdom see Disney and Gosling (1998) and Table 7 below. For the United States see Poterba and Rueben (1994).
} 
as health and education that were not directly privatised, although they became more integrated into the private sector over the period.

It is important, however, to separate pure public sector wage compression effects from union wage compression effects. Panel B of Table 7 shows that union membership and public sector employment are two closely linked phenomena. For both men and women in 1983 and 1998, the rate of union membership in the public sector is about 40

percentage points larger than in the private sector. More importantly, coverage in the public sector is close to $90 \%$. The last four rows of Table 7 show, however, that most of the difference in the wage distributions between the public and private sectors are a consequence of the fact that unions are more present in the public than private sector. Conditional on union status, the table shows that the standard deviation of wages is not systematically smaller in the public than private sector. It is particularly clear in the case of men that the key determinant of wage inequality is union status as opposed to public sector affiliation. This means that the effect of privatisation on the wage structure may have occurred indirectly through decreasing the likelihood that lower-paid workers would be unionised.

The other issue is that many workers affected by changes in the state's employment policy are still working in the public sector. Competitive tendering, where an activity stays in the public sector only if it has lower costs than can be found in the private sector has meant that public and private sector wages have converged. Disney and Gosling (1998) find that the wage distribution of low skilled men is basically identical in the two sectors in the 1990s. This, when taken together with the points made in the paragraph above, means that the effect of privatisation is going to be hard to uncover. In fact when we perform the same kind of counterfactual decomposition for the public sector than we did for unions in Table 6, we find only negligible effects on wage inequality.

\section{Effect of Reforms on Wage Inequality: Qualifications and Extensions}

The empirical analysis above supports the simple story. Wage inequality increased fastest for U.S. women during the 1980s because of the decline in the minimum wage. Over the 
1980s and 1990s inequality increased for men faster in the United Kingdom because of the decline in unionisation. In this section we discuss some possible arguments for and against this view in more detail.

\section{1. "Causality" of the effect of unions on wage inequality}

Our findings in Section 3.2 can only be interpreted as the causal effect of the reduction of unionisation on wage inequality if the unobserved characteristics of union members are the same as workers not in unions. If this assumption does not hold, then we cannot tell how much of the changes in wage inequality that we attribute to de-unionisation are a real causal effect of de-unionisation, as opposed to spurious consequences of changes in the distribution of unobservables between the union and nonunion sectors. If workers and firms respond to incentives at all, then this assumption will be violated. The real question is therefore whether all the changes that we attribute to unionisation just reflect differences in unobservables. This is not testable, in general, but we believe it is unlikely for the following reasons.

First, the difference between the raw effects (Table 4) and those obtained by controlling for a large set of explanatory variables (Table 6) are small. Unless unobservables play a radically different role in the determination of the union status of workers than observables like age and education, failure to control for unobservables should not affect significantly the results. Furthermore, if selection effects are important because firms and workers respond to wage differentials, then we know that the true effects must lie somewhere greater than zero and less than the estimated effects.

Another reason to believe that our results can be interpreted as a "causal" effect of unionisation is that existing studies that have modelled more explicitly the selection problem found that doing so did not have much impact on the estimated effect of unions on wage inequality. For example, both Freeman (1993) and Card (1992) use fixed effect methods to control for difference in the distribution of person-specific unobservables between the union and non-union sectors. They conclude that these adjusted estimates yield a very similar impact of de-unionisation on the growth in U.S. male wage inequality than simpler cross-sectional estimates like the ones considered here. 
A more subtle point raised by Lewis (1986) is that these various estimators only yield a "causal" estimate of union wage effects under the assumption that the extent of unionisation has no effect on nonunion wages. This assumption would be violated, however, in the presence "threat" or other general equilibrium effects. If these effects are important, we may either be understating or overstating the "true" effect of deunionisation on wage inequality. For instance, Freeman (1996) has argued that, because of threat effects, standard estimates of the effect of de-unionisation on wage inequality likely understate the full effect. The basic idea s that as unions get weaker and the threat of unionisation weakens, non-union firms no longer feel compelling to "imitate" the wage structure of union firms to avoid unionisation. In this light Gosling (1998) relates wages at the workplace level to the threat of unionisation when the establishment was set up, conditional on fixed industry and establishment age/cohort effects. This paper finds the threat of unionisation has a bigger effect on the dispersion of wages than actual union status.

The changes in the distribution of union and nonunion wages in the U.K. documented in Table 4 and Appendix Figure 1 are consistent with this view. There is much less difference between the distributions of union and nonunion wages in the U.K. in 1983, when unions are quite strong, than in 1998 or in the United States where they are weaker. In other words, the fact that wage inequality in the nonunion sector expanded so fast in the United Kingdom between 1983 and 1998 is consistent with the view that the threat of unionisation subsumed during this period. Attributing part of this expansion in wage inequality to de-unionisation would increase substantially the estimated effect of deunionisation on wage inequality.

\subsection{Comparison with other periods and other countries.}

Our original motivation for looking at the effect of unions on wage inequality was that male wage inequality expanded much faster in the United Kingdom, where the rate of unionisation declined by 25 percentage points between 1983 and 1998, than in the United States where it declined by less than 10 percentage points. This "aggregate" evidence is, in itself, inconsistent with simple selection bias explanation. If being a union 
member was just a "label" for unobservable characteristics, then changes in wage inequality should be unrelated, on average, with changes in the rate of unionisation.

We explore this aggregate evidence in more detail in Figure 10 which shows the evolution of the U.K.-U.S. differences in unionization and in the variance of male wages, respectively, between 1979 and 1998. ${ }^{31}$ Interestingly, both series exhibit a break in trend around 1983. Between 1979 and 1983, the variance of male wages increases faster in the United States than in the United Kingdom while unionization decreases at the same pace in the two countries. After 1983, however, U.K. unionization rates fall faster than in the United States while the variance of U.K. wage expands faster than in the United States. The coincidence in the trend breaks in the two series strongly supports our earlier conclusion about the role of unions in the relative evolution of male wage inequality in the two countries.

A simple OLS regression of the U.K.-U.S. difference in the variance of wages on the difference in unionization rates indicates yields an estimated coefficient of 0.22 (with a standard error of 0.03). The Rsquare from the regression is 0.74 , suggesting that the differential evolution of unionization in the two countries account for most of the divergent trends in male wage inequality. As in the case of the minimum wage analysis for women illustrated in Figure 8, a linear trend is not statistically significant once differences in unionization are controlled for.

Taken at face value, the estimated "aggregate" effects imply that de-unionization accounts for $35 \%$ of the 0.068 increase in the variance of wages in the United States between 1979 and 1998, and for $53 \%$ of corresponding 0.097 increase in the variance in the United Kingdom. ${ }^{32}$ Another interesting observation is that while the rate of unionization in 1998 is quite close to the U.S. rate for 1979 (see Figure 9), the extent of male wage inequality in the United Kingdom in 1998 is also quite similar to the U.S. one for 1979 (see Figure 2). A related point is that, according to the estimated regression model, the $16 \%$ remaining unionization rate gap in 1998 should translate into a 0.035 variance gap which is very close to the 0.04 gap observed in Figure 10. In other words,

\footnotetext{
${ }^{31}$ As in the case of women in Figure 8, we smooth the U.K. variance of wages using a three-year moving average before computing the U.K.-U.S. difference in the variance of wages. We also use the overall rate of unionisation, as opposed to the rate for men only, because of data limitations.
} 
the regression estimates predict that the U.K.-U.S. variance gap would basically vanish if the U.K. unionization rate was to decline all the way to the U.S. level. So in addition to explaining well the differential evolution of male wage inequality in the two countries, U.K.-U.S. differences in unionization also seem to explain quite well the difference in the level of wage inequality.

Interestingly, these findings are qualitatively similar to those of DiNardo and Lemieux (1997) who show that male wage inequality increased much less in the Canada than in the United States between 1981 and 1988. By contrast, the rate of unionisation remained relatively stable in Canada while it dropped sharply in the United States during this period. Putting these pieces of "aggregate" evidence together reinforces our earlier conclusion that unionisation is an important explanation for the U.K.-U.S. convergence in male wage inequality over the last two decades.

Comparisons with other European countries are more challenging because wagesetting institutions in countries like France and Germany are quite different from the decentralized (or absence of) collective bargaining that prevails in the United Kingdom, the United States, or Canada. But as mentioned in the introduction, wage-setting institutions remained relatively stable in those two countries compared to the United Kingdom. The fact that inequality also remained stable and France and Germany suggest that institutional changes can account for differential changes in wage inequality both between the United Kingdom and the United States and between the United Kingdom and France and Germany.

\subsection{Is the decline in unionisation exogenous?}

One possible objection against this aggregate evidence is that de-unionisation is just an endogenous consequence of more fundamental labour market changes like skillbiased technical change that are the real underlying source of increase in wage inequality. ${ }^{33}$ If this is true, however, then the rate of technical change (or other underlying change) must have been higher in the United Kingdom than in the United

\footnotetext{
32 These estimates are obtained by multiplying the estimated coefficient of 0.22 by the respective declines of unionization in the United States (0.11) and the United Kingdom (0.23).

${ }^{33}$ See, for example, Acemoglu, Aghion, and Violante (2000).
} 
States, France and Germany, which is neither an appealing nor a parsimonious explanation.

The alternative explanation we implicitly have in mind here is that at least some of the U.K. changes in unionisation have occurred because of changes in the legal framework rather than changes to labour market and product market conditions. Under this scenario, ascribing a causal role for the decline in unionisation is more plausible.

As Pencavel (this volume) shows, there is probably no single reason why unionisation declined so rapidly over the 1980s and 1990s. It is, however, plausible that legislation (especially the employment acts of 1980 and 1982) did have a crucial role. These acts increased the costs of unionisation by removing union immunities in a recognition dispute. ${ }^{34}$ Previously unions could obtain negotiating rights by threatening to go on strike. ${ }^{35}$ The strike weapon was still available but unions were now liable for monies lost to their employer as a result of the dispute. Put simply, the threat of a strike in this instance became less credible. Disney, Gosling and Machin $(1995,1996)$ show that it is conditions surrounding the workplace at set up date rather than current conditions which determine the probability of unionisation. They also find, even after controlling for industry level conditions of the labour and product market and macro variables at set up date and current establishment level characteristics (such as size), that workplaces established in the 1980 s are more than $16 \%$ less likely to be unionised. ${ }^{36}$ The aggregate decline carried on through the 1980s as the proportion of post 1980s workplaces in the sample increased. Again, this is consistent with the view that part of the decline in unionisation was a result of the 1980s legislative changes.

Of course it is still possible that it is not legislation which is driving the down turn but another discrete jump in the cost of unionisation. ${ }^{37}$ This could be driven by changes in the relative productivity of skilled or unskilled workers, changes in technology reducing the beneficial effects of collective voice and increases in competition. The issue is then why these caused a discrete jump in 1980. A more plausible story is that the legislative

\footnotetext{
${ }^{34}$ A union is "recognised" when there it has negotiating rights with the employer for determining pay and conditions of employment.

${ }^{35}$ Up until July 2000, employers were under no obligation to negotiate with unions even if all of their employees wanted it

${ }^{36}$ This 1980s "shift" effect was the only establishment cohort variable to be significant in both statistical and quantitative terms
} 
changes allowed management to respond faster to these increases in costs. The story for U.K. men is then that the change in the structure of demand increased wage inequality both directly and because of the legislative changes indirectly through the removal of pay-setting institutions that increased wages at the bottom end.

\section{Conclusion}

This paper compares trends in male and female hourly wage inequality in the United Kingdom and the United States between 1979 and 1998. Our main finding is that the extent and pattern of wage inequality became increasingly similar in the two countries during this period. We attribute this convergence to "U.S. style" reforms in the U.K. labour market. In particular, we argue that the much steeper decline in unionisation in the United Kingdom explains why inequality increased faster than in the United States. For women, we conclude that the fall and subsequent recovery in the real value of the U.S. minimum wage explains why wage inequality increased faster in the United States than in the United Kingdom during the 1980s, while the opposite happened during the 1990s. The introduction of the National Minimum Wage in the United Kingdom in 1999 also contributed to the convergence in labour market institutions and wage inequality between the two countries. Finally, our "institutional" explanation for the differential evolution of wage inequality in the United Kingdom and the United States is also a natural explanation for the difference between the United Kingdom and France and Germany, where both wage inequality and wage-setting institutions remained relatively stable over the last two decades.

\footnotetext{
${ }^{37}$ see again Acemoglu, Aghion and Violante (2000)
} 


\section{REFERENCES}

Acemoglu, Daron, Philippe Aghion and G. Violante. 2000. "De-unionisation, technical change and inequality" UCL mimeo

Beaudry, Paul, and David Green. 2000. "The changing structure of wages in the US and Germany: What explains the difference?" National Bureau of Economic Research Working Paper No. 7697

Blau, Francine. 1998. "Trends in the well being of American women 1970-1995" Journal of Economic Literature 36 (1): 112-165

Card, David, 1992,"The Effect of Unions on the Distribution of Wages: Redistribution or Relabelling?," National Bureau of Economic Research Working Paper No. 4195

Card, David, Francis Kramarz, and Thomas Lemieux. 1999. "Changes in the Relative Structure of Wages and Employment: A Comparison of the United States, Canada, and France," Canadian Journal of Economics 32 (4): 843-877

Card, David, and Thomas Lemieux. 2001. "Can Falling Supply Explain the Rising Return to College for Younger Men? A Cohort-Based Analysis" Quarterly Journal of Economics 116(2), 42 pages.

DiNardo, John, Nicole M. Fortin, and Thomas Lemieux. 1996. "Labor Market Institutions and the Distribution of Wages, 1973-1992: A Semiparametric Approach," Econometrica 65 (5): 1001-1046.

DiNardo, John, and Thomas Lemieux. 1997. "Changes in Wage Inequality in Canada and the United States: Do Institutions Explain the Difference?" Industrial and Labor Relations Review 50 (4): 629-651.

Disney, Richard, and Amanda Gosling. 1998. "Does it pay to work in the public sector?" Fiscal Studies 19 (4): 347-374

Disney, Richard, Amanda Gosling, and Steve Machin. 1995. "British unions in decline: determinants of the 1980s fall in union recognition" Industrial and Labor Relations Review 48 (3): 403-419

Disney, Richard, Amanda Gosling, and Steve Machin. 1996. "What has happened to union recognition in Britain?" Economica 63 (249): 1-18

Freeman, Richard. 1980. "Unionism and the Dispersion of Wages," Industrial and Labor Relations Review 34 (1): 3-23

Freeman, Richard. 1982. "Union wage practices and wage dispersion within establishments" Industrial and Labor Relations Review 36: 3-21 
Freeman, Richard. 1993. "How much Has De-unionisation Contributed to the Rise in Male Earnings Inequality?" In Danziger, Sheldon, and Peter Gottschalk, eds., Uneven Tides: Rising Inequality in America. New York: Russell Sage Foundation: 133-163

Freeman, Richard. 1996. "Labor Market Institutions and Earnings Inequality," New England Economic Review (May/June): 157-168

Freeman, Richard, and Lawrence Katz. 1996. "Introduction and Summary." In Richard Freeman, and Lawrence Katz, eds., Differences and Changes in Wage Structures. Chicago: University of Chicago Press and NBER: 1-22

Freeman, Richard, and Karen Needels. 1993. "Skill Differentials in Canada in an Era of Rising Labor Market Inequality." In Card, David, and Richard B. Freeman, eds., Small Differences that Matter: Labor Markets and Income Maintenance in Canada and the United States. Chicago: University of Chicago Press: 45-67

Giles Christopher, Amanda Gosling, Francois Laisney, and Thorsten Geib. 1998. "The distribution of income and wages in the UK and West Germany 1984-1992" IFS mimeo

Gosling, Amanda. 1998. "The Determination of Union Status and Wages in British Establishments" Department of Economics University of Essex working paper No 491

Gosling, Amanda, and Steve Machin, "Trade Unions and the Dispersion of Earnings in British Establishments," Oxford Bulletin of Economics and Statistics 56 (?): 167-84.

Gosling, Amanda, Steve Machin and Costas Meghir, 2000."The changing distribution of male wages in the UK" Review of Economic Studies 67 (4): 635-686.

Harkness Susan. 1996. "The gender earnings gap: evidence from the UK" Fiscal studies 17 (2): $1-36$

Katz, Lawrence, and Kevin Murphy. 1992. "Changes in Relative Wages, 1963-1987:

Supply and Demand Factors," Quarterly Journal of Economics 107 (1): 35-78

Lee, David. 1999. "Wage Inequality in the United States during the 1980s: Rising Dispersion or Falling Minimum Wage?', Quarterly Journal of Economics 114 (3): 9771023

Lemieux, Thomas. 1993. "Unions and Wage Inequality in Canada and the United States." In Card, David, and Richard B. Freeman, eds., Small Differences that Matter: Labor Markets and Income Maintenance in Canada and the United States. Chicago: University of Chicago Press: 69-107.

Lewis, H. Gregg. 1986. Union relative wage effects : a survey. Chicago University of Chicago Press 
Machin, Steve. 1996. "Wage inequality in the UK," Oxford Review of Economic Policy 12 (1): 47-64

Metcalf, David. 1977. "Unions, incomes policies and relative wages in Britain," British Journal of Industrial Relations 20 (2): 157-190

Metcalf, David. 1982. "Unions and the dispersion of Earnings," British Journal of Industrial Relations 20 (2): 170-185

Pencavel, John. 2001. “The Surprising Retreat of Union Britain”, this volume.

Poterba, James, and Kim Rueban. 1994. "The Distribution of Public Sector Wage Premia: New Evidence Using Quantile Regression Methods," National Bureau of Economic Research Working Paper No. 4734

Schmitt, John. 1996. "The Changing Structure of Male Earnings in Britain, 1974-88" in Richard B. Freeman and Lawrence F. Katz, eds., Differences and Changes in Wage Structures, Chicago: University of Chicago Press and NBER: 177-204.

Stewart, Mark. 1983. "Relative earnings and individual union membership in the UK" Economica 50 (198): 111-25. 
TABLES AND FIGURES 
Table 1: Measures of $(\log )$ wage inequality in the United Kingdom and the United States, 1979-1998

\begin{tabular}{|c|c|c|c|c|c|c|}
\hline & $\begin{array}{r}1979 \\
(1)\end{array}$ & $\begin{array}{r}1989 \\
(2)\end{array}$ & $\begin{array}{r}1998 \\
(3)\end{array}$ & $\begin{array}{r}79-89 \\
\text { Change } \\
(4)\end{array}$ & $\begin{array}{r}89-98 \\
\text { Change } \\
(5)\end{array}$ & $\begin{array}{r}79-98 \\
\text { Change } \\
(6)\end{array}$ \\
\hline \multicolumn{7}{|c|}{ A. United Kingdom, men } \\
\hline $50-10$ & 0.408 & 0.529 & 0.550 & 0.121 & 0.021 & 0.142 \\
\hline $90-50$ & 0.512 & 0.630 & 0.640 & 0.118 & 0.009 & 0.128 \\
\hline $90-10$ & 0.920 & 1.159 & 1.189 & 0.239 & 0.030 & 0.269 \\
\hline Standard Deviation & 0.376 & 0.464 & 0.501 & 0.088 & 0.038 & 0.125 \\
\hline \multicolumn{7}{|c|}{ B. United Kingdom, women } \\
\hline $50-10$ & 0.399 & 0.494 & 0.576 & 0.095 & 0.082 & 0.177 \\
\hline $90-50$ & 0.599 & 0.717 & 0.693 & 0.119 & -0.025 & 0.094 \\
\hline $90-10$ & 0.998 & 1.211 & 1.269 & 0.213 & 0.058 & 0.271 \\
\hline Standard Deviation & 0.409 & 0.486 & 0.503 & 0.077 & 0.017 & 0.094 \\
\hline \multicolumn{7}{|c|}{ C. United States, men } \\
\hline $50-10$ & 0.650 & 0.737 & 0.688 & 0.087 & -0.049 & 0.038 \\
\hline $90-50$ & 0.552 & 0.639 & 0.699 & 0.087 & 0.060 & 0.147 \\
\hline $90-10$ & 1.201 & 1.376 & 1.386 & 0.175 & 0.011 & 0.185 \\
\hline Standard Deviation & 0.460 & 0.527 & 0.529 & 0.068 & 0.001 & 0.069 \\
\hline \multicolumn{7}{|c|}{ D. United States, women } \\
\hline $50-10$ & 0.439 & 0.631 & 0.567 & 0.192 & -0.064 & 0.128 \\
\hline $90-50$ & 0.575 & 0.642 & 0.728 & 0.067 & 0.086 & 0.153 \\
\hline $90-10$ & 1.015 & 1.273 & 1.295 & 0.258 & 0.022 & 0.281 \\
\hline Standard Deviation & 0.418 & 0.500 & 0.502 & 0.082 & 0.003 & 0.084 \\
\hline
\end{tabular}

Note: Based on hourly wages of wage and salary workers age 23 to 59 earning between 1 and 30 pounds per hour (1996 pounds) in the United Kingdom, and between 2.5 and 63 dollars an hour (1996 dollars) in the United States. U.S. data are from the outgoing rotation group files of the Current Population Survey. Measures of wage dispersion for the United Kingdom in 1979 and 1989 are three-year averages from the Family Expenditure Survey for 1978-1980 and 1988-1990, respectively. Measures of wage dispersion for 1998 are computed using data from the Fall Labour Force Survey 
Table 2: Standard Wage Differentials and Between- and Within-Group Variance of Wages in the United Kingdom and the United States, 1979-1998

\begin{tabular}{rrrrrrr}
\hline \hline 1979 & 1989 & 1998 & $79-89$ & $89-98$ & $79-98$ \\
Change & Change & Change \\
& & & $(3)$ & $(4)$ & $(5)$ & $(6)$ \\
\hline
\end{tabular}

A. United Kingdom, men

$\begin{array}{lrrrrrr}\text { A-O level/No qual. } & 0.248 & 0.288 & 0.246 & 0.040 & -0.042 & -0.002 \\ \text { Univ./A-O level } & 0.231 & 0.242 & 0.375 & 0.011 & 0.133 & 0.144 \\ \text { Age 40-49/23-29 } & 0.191 & 0.245 & 0.308 & 0.054 & 0.063 & 0.117 \\ & & & & & & \\ \text { Between Variance } & 0.0386 & 0.0591 & 0.0781 & 0.0205 & 0.0190 & 0.0395 \\ \text { Within Variance } & 0.1000 & 0.1427 & 0.1730 & 0.0427 & 0.0303 & 0.0730\end{array}$

B. United Kingdom, women

$\begin{array}{llllrrr}\text { A-O level/No qual. } & 0.208 & 0.292 & 0.243 & 0.084 & -0.049 & 0.035 \\ \text { Univ./A-O level } & 0.520 & 0.400 & 0.490 & -0.120 & 0.090 & -0.030 \\ \text { Age 40-49/23-29 } & 0.014 & 0.009 & 0.092 & -0.005 & 0.083 & 0.078\end{array}$

$\begin{array}{lllllll}\text { Between Variance } & 0.0480 & 0.0759 & 0.0850 & 0.0279 & 0.0091 & 0.0370\end{array}$

$\begin{array}{lllllll}\text { Within Variance } & 0.1119 & 0.1562 & 0.1682 & 0.0443 & 0.0120 & 0.0563\end{array}$

C. United States, men

$\begin{array}{lrrrrrr}\text { HS/Dropout } & 0.221 & 0.247 & 0.285 & 0.026 & 0.038 & 0.064 \\ \text { College/HS } & 0.216 & 0.342 & 0.416 & 0.126 & 0.074 & 0.200 \\ \text { Post Grad/College } & 0.044 & 0.091 & 0.157 & 0.047 & 0.066 & 0.113 \\ \text { Age 40-49/23-29 } & 0.297 & 0.357 & 0.325 & 0.060 & -0.032 & 0.028\end{array}$

$\begin{array}{lllllll}\text { Between Variance } & 0.0496 & 0.0833 & 0.0934 & 0.0337 & 0.0101 & 0.0438 \\ \text { Within Variance } & 0.1617 & 0.1901 & 0.1903 & 0.0284 & 0.0002 & 0.0286\end{array}$

D. United States, women

$\begin{array}{lllllll}\text { HS/Dropout } & 0.175 & 0.251 & 0.274 & 0.076 & 0.023 & 0.099 \\ \text { College/HS } & 0.260 & 0.418 & 0.481 & 0.158 & 0.063 & 0.221 \\ \text { Post Grad/College } & 0.170 & 0.180 & 0.203 & 0.010 & 0.023 & 0.033 \\ \text { Age 40-49/23-29 } & 0.078 & 0.175 & 0.230 & 0.097 & 0.055 & 0.152\end{array}$

$\begin{array}{lllllll}\text { Between Variance } & 0.0323 & 0.0715 & 0.0809 & 0.0392 & 0.0094 & 0.0486\end{array}$

\begin{tabular}{lllllll} 
Within Variance & 0.1310 & 0.1827 & 0.1733 & 0.0517 & -0.0094 & 0.0493 \\
\hline
\end{tabular}

Note: Based on hourly wages of wage and salary workers age 23 to 59 earning between 1 and 30 pounds per hour (1996 pounds) in the United Kingdom, and between 2.5 and 63 
dollars an hour (1996 dollars) in the United States. U.S. data are from the outgoing rotation group files of the Current Population Survey. Measures of wage dispersion for the United Kingdom in 1979 and 1989 are three-year averages from the General Household Survey for 1978-1980 and 1988-1990, respectively. Measures of wage dispersion for 1998 are computed using data from Fall Labour Force Survey. The decomposition of the variance of log wages between and within groups is carried over by estimating log wage regression with a set of regional dummies (ten regions and London in the United Kingdom, nine regions and SMSA status in the United States), a dummy variable for marital status, and a set of education dummies (seven in the United Kingdom, five in the United States) fully interacted with a fourth degree polynomial in age as regressors. U.S. models also include dummy variables for race and veteran status. 
Table 3: Simulated and Actual Effect of the 1999 Minimum Wage on the U.K. Wage Distribution

\begin{tabular}{|c|c|c|c|c|}
\hline & Actual 1998 & $\begin{array}{r}\text { Simulated } 1998 \\
\text { with } £ 3.60 \\
\text { minimum wage }\end{array}$ & Actual 1999 & $\begin{array}{r}\text { Actual } 1999 \\
\text { with new hourly } \\
\text { wage data }\end{array}$ \\
\hline & (1) & (2) & (3) & (4) \\
\hline \multicolumn{5}{|l|}{ A. MEN } \\
\hline $5^{\text {th }}$ percentile & 3.84 & 3.84 & 4.04 & 4.00 \\
\hline 10th percentile & 4.48 & 4.48 & 4.71 & 4.60 \\
\hline 90-10 log wage & 1.273 & 1.273 & 1.273 & 1.297 \\
\hline Standard deviation & 0.502 & 0.488 & 0.504 & 0.501 \\
\hline \multicolumn{5}{|l|}{ B. WOMEN } \\
\hline $5^{\text {th }}$ percentile & 3.00 & 3.60 & 3.30 & 3.60 \\
\hline 10th percentile & 3.41 & 3.60 & 3.67 & 3.70 \\
\hline 90-10 log wage & 1.271 & 1.216 & 1.238 & 1.225 \\
\hline Standard deviation & 0.502 & 0.472 & 0.497 & 0.480 \\
\hline \multicolumn{5}{|l|}{ C. MEN-WOMEN } \\
\hline 90-10 log wage & 0.002 & 0.057 & 0.035 & 0.072 \\
\hline Standard deviation & 0.000 & 0.016 & 0.007 & 0.021 \\
\hline
\end{tabular}

Note: Statistics computed using data from the 1998 and 1999 Fall Labour Force Survey for wage and salary workers age 23 to 59 earning between 1.06 and 31.8 pounds per hour (between 1 and 30 pounds in 1996 pounds). The simulated effect of the minimum wage (column 2) is obtained by assuming that two thirds of workers earning less than $£ 3.6$ in the Fall of 1998 would have earned exactly the 1999 National Minimum Wage of $£ 3.6$ if the 1999 National Minimum Wage had prevailed in 1998. The wage of the other third of subminimum workers are assumed to be unaffected by the minimum wage. In column 4, the (new) direct information on hourly wage rates is used instead of average hourly earnings whenever available. 
Table 4: Variance decomposition of log hourly wages between and within the union and non-union sectors in the United Kingdom and the United States

\begin{tabular}{|c|c|c|c|c|c|c|}
\hline & \multicolumn{3}{|c|}{ United Kingdom } & \multicolumn{3}{|c|}{ United States } \\
\hline & $\begin{array}{l}198 \overline{3} \\
(1)\end{array}$ & $\begin{array}{l}1998 \\
(2)\end{array}$ & $\begin{array}{c}\text { Change } \\
\text { (3) }\end{array}$ & $\begin{array}{l}1983 \\
(4)\end{array}$ & $\begin{array}{l}1998 \\
(5)\end{array}$ & $\begin{array}{c}\text { Change } \\
\text { (6) }\end{array}$ \\
\hline A. MEN & & & & & & \\
\hline $\begin{array}{l}\text { 1. Variance in union } \\
\text { sector }\end{array}$ & 0.139 & 0.180 & 0.041 & 0.133 & 0.173 & 0.040 \\
\hline $\begin{array}{l}\text { 2. Variance in non union } \\
\text { sector }\end{array}$ & 0.219 & 0.288 & 0.069 & 0.296 & 0.305 & 0.008 \\
\hline $\begin{array}{l}\text { 3. Union wage } \\
\text { differential }\end{array}$ & 0.094 & 0.089 & -0.004 & 0.150 & 0.138 & -0.012 \\
\hline 4. Unionisation rate & 0.610 & 0.358 & -0.252 & 0.277 & 0.182 & -0.095 \\
\hline $\begin{array}{l}\text { 5. Overall variance } \\
6 \text { Variance with } 1983\end{array}$ & 0.172 & 0.251 & 0.079 & 0.256 & 0.284 & 0.028 \\
\hline unionisation rate & 0.172 & 0.224 & 0.052 & 0.256 & 0.272 & 0.016 \\
\hline $\begin{array}{l}\text { 7. "De-unionisation" effect } \\
\text { (\% of total) }\end{array}$ & & & $\begin{array}{l}0.027 \\
(34.4)\end{array}$ & & & $\begin{array}{l}0.012 \\
(41.4)\end{array}$ \\
\hline $\begin{array}{l}\text { B. WOMEN } \\
\text { 1. Variance in union }\end{array}$ & & & & & & \\
\hline sector & 0.169 & 0.209 & 0.040 & 0.164 & 0.220 & 0.057 \\
\hline $\begin{array}{l}\text { 2. Variance in non union } \\
\text { sector }\end{array}$ & 0.176 & 0.242 & 0.066 & 0.203 & 0.252 & 0.048 \\
\hline $\begin{array}{l}\text { 3. Union wage } \\
\text { differential }\end{array}$ & 0.255 & 0.310 & 0.056 & 0.238 & 0.242 & 0.003 \\
\hline 4. Unionisation rate & 0.456 & 0.330 & -0.126 & 0.168 & 0.128 & -0.040 \\
\hline 5. Overall variance & 0.188 & 0.253 & 0.065 & 0.205 & 0.254 & 0.050 \\
\hline $\begin{array}{l}\text { 6. Variance with } 1983 \\
\text { unionisation rate }\end{array}$ & 0.189 & 0.251 & 0.062 & 0.205 & 0.255 & 0.050 \\
\hline $\begin{array}{l}\text { 7. "De-unionisation" effect } \\
\text { (\% of total) }\end{array}$ & & & $\begin{array}{r}0.003 \\
(4.6)\end{array}$ & & & $\begin{array}{l}0.000 \\
(-0.9)\end{array}$ \\
\hline
\end{tabular}

Note: Based on hourly wages of wage and salary workers age 23 to 59 earning between 1 and 30 pounds per hour (1996 pounds) in the United Kingdom, and between 2.5 and 63 dollars an hour (1996 dollars) in the United States. U.S. data are from the outgoing rotation group files of the Current Population Survey. 1983 U.K. data are from the General Household Survey; 1998 U.K. data are from the Fall Labour Force Survey. Workers are divided between the "union" and "non-union" sectors on the basis of their self-reported membership to a trade union. The simulated variance in row 6 is computed using a standard variance decomposition formula (see note at the bottom of Table 5). 
Table 5: Simulated variance of male log wages in the United Kingdom and the United States under different unionisation rates.

\begin{tabular}{|c|c|c|c|}
\hline \multirow[b]{2}{*}{$\begin{array}{l}\text { Simulated variance of wages } \\
\text { in } 1983 \text { in the: }\end{array}$} & \multicolumn{2}{|c|}{ Simulated Unionisation Rate } & \multirow[b]{2}{*}{ U.S. $(28 \%)$} \\
\hline & Actual & U.K. $(61 \%)$ & \\
\hline United Kingdom & 0.172 & 0.172 & 0.198 \\
\hline United States & 0.256 & 0.202 & 0.256 \\
\hline Difference & 0.084 & 0.03 & 0.058 \\
\hline \multirow[t]{2}{*}{ (\% of actual difference) } & 100 & 36 & 69 \\
\hline & \multicolumn{2}{|c|}{ Simulated Unionisation Rate } & \\
\hline $\begin{array}{l}\text { Simulated variance of wages } \\
\text { in } 1998 \text { in the: }\end{array}$ & Actual & U.K. $(36 \%)$ & U.S. $(18 \%)$ \\
\hline United Kingdom & 0.251 & 0.251 & 0.270 \\
\hline United States & 0.284 & 0.262 & 0.284 \\
\hline Difference & 0.033 & 0.011 & 0.014 \\
\hline (\% of actual difference) & 100 & 33 & 42 \\
\hline
\end{tabular}

Note: The variances are computed using the standard variance decomposition formula: $\operatorname{Var}(\mathrm{w})=\hat{\mathrm{U}} \operatorname{Var}(\mathrm{w} \mid \mathrm{U}=1)+(1-\hat{\mathrm{U}}) \operatorname{Var}(\mathrm{w} \mid \mathrm{U}=0)+\hat{\mathrm{U}}(1-\hat{\mathrm{U}}) \ddot{\mathrm{A}}$, where $\hat{\mathrm{U}}$ is the unionisation rate (actual or simulated), and $\ddot{\mathrm{A}}$ is the difference in mean wages between the union and nonunion sectors $(\mathrm{E}(\mathrm{w} \mid \mathrm{U}=1)-\mathrm{E}(\mathrm{w} \mid \mathrm{U}=0))$. 
Table 6: Effect of De-unionisation on Log Hourly Wage Inequality Adjusting for Composition Effects.

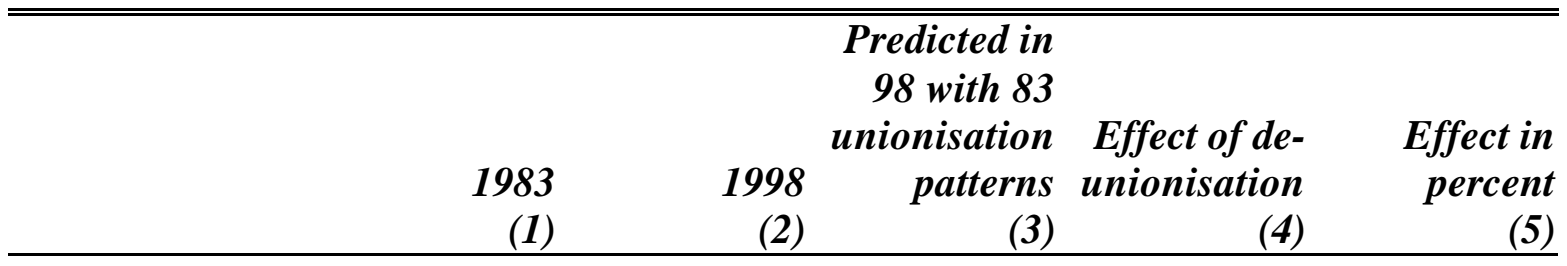

A. U.K. Men

Unionisation

61.1

35.4

58.3

Variance

0.172

0.250

0.225

0.025

32.5

90-10

1.025

1.275

1.208

0.067

26.8

90-50

0.554

0.685

0.627

0.058

44.3

50-10

0.472

0.590

0.580

0.010

8.5

B. U.S. Men

Unionisation

27.4

18.2

26.2

Variance

0.255

0.279

0.271

0.008

90-10

1.314

1.386

1.375

0.011

15.8

90-50

0.602

0.699

0.693

0.005

5.6

$50-10$

0.712

0.688

0.682

0.006

Note: The simulated measures of wage dispersion in column 3 are computed by "reweighting" the 1998 data by the ratio of the predicted probabilities of union membership in 1983 and 1998. The predicted probabilities are estimated using a logit model for union membership. Explanatory variables used are a set of regional dummies (ten regions and London in the United Kingdom, nine regions and SMSA status in the United States), a dummy variable for marital status, and a set of education dummies (seven in the United Kingdom, five in the United States) fully interacted with a fourth degree polynomial in age. U.S. models also include dummy variables for race and veteran status 
Table 7: Distribution of Workers and Wage Dispersion in the Public and Private Sector in the United Kingdom

\begin{tabular}{|c|c|c|c|c|}
\hline & \multicolumn{2}{|c|}{ Men } & \multicolumn{2}{|c|}{ Women } \\
\hline & 1983 & 1998 & 1983 & 1998 \\
\hline \multicolumn{5}{|c|}{ A. Percentage of workers in the Public Sector: } \\
\hline & 37.5 & 21.8 & 42.1 & 36.5 \\
\hline \multicolumn{5}{|c|}{ B. Unionisation rate in: } \\
\hline Public Sector: & 87.3 & 67.5 & 69.7 & 59.2 \\
\hline Private Sector: & 45.4 & 26.5 & 28.6 & 17.3 \\
\hline \multicolumn{5}{|c|}{ C. Standard deviation of wages in: } \\
\hline Public Sector: & 0.416 & 0.456 & 0.387 & 0.463 \\
\hline Private Sector: & 0.398 & 0.507 & 0.439 & 0.499 \\
\hline Union, public: & 0.385 & 0.430 & 0.432 & 0.438 \\
\hline Union, private: & 0.348 & 0.408 & 0.334 & 0.453 \\
\hline Nonunion, public: & 0.477 & 0.504 & 0.439 & 0.447 \\
\hline Nonunion, priv.: & 0.465 & 0.538 & 0.397 & 0.502 \\
\hline
\end{tabular}

Note: All statistics are computed from a sample of wage and salary workers age 23 to 59 earning between 1 and 30 pounds per hour (1996 pounds) from the 1983 General Household Survey and the 1998 Fall Labour Force Survey. 

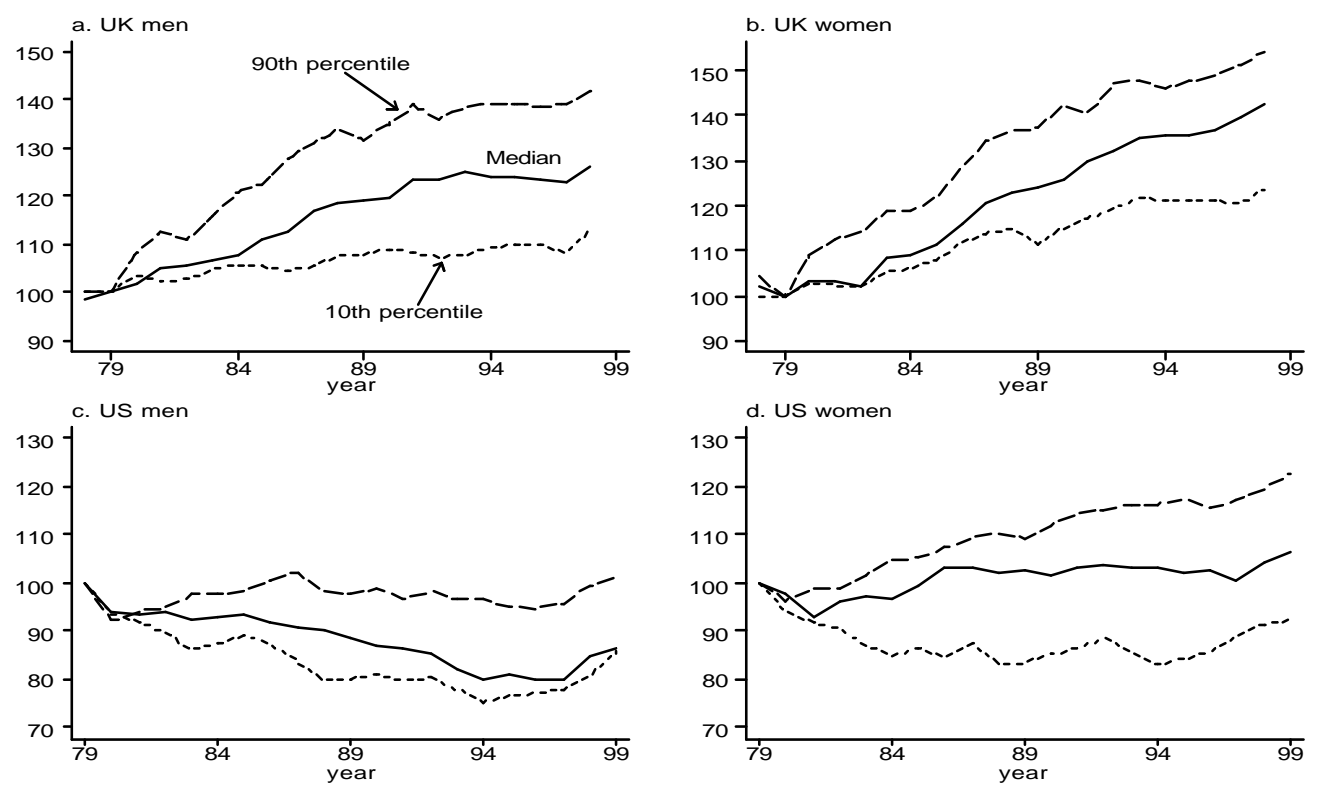

Figure 1: Indexed Real Wages by Percentile, 1978-1999

U.K and U.S., $1979=100$ 

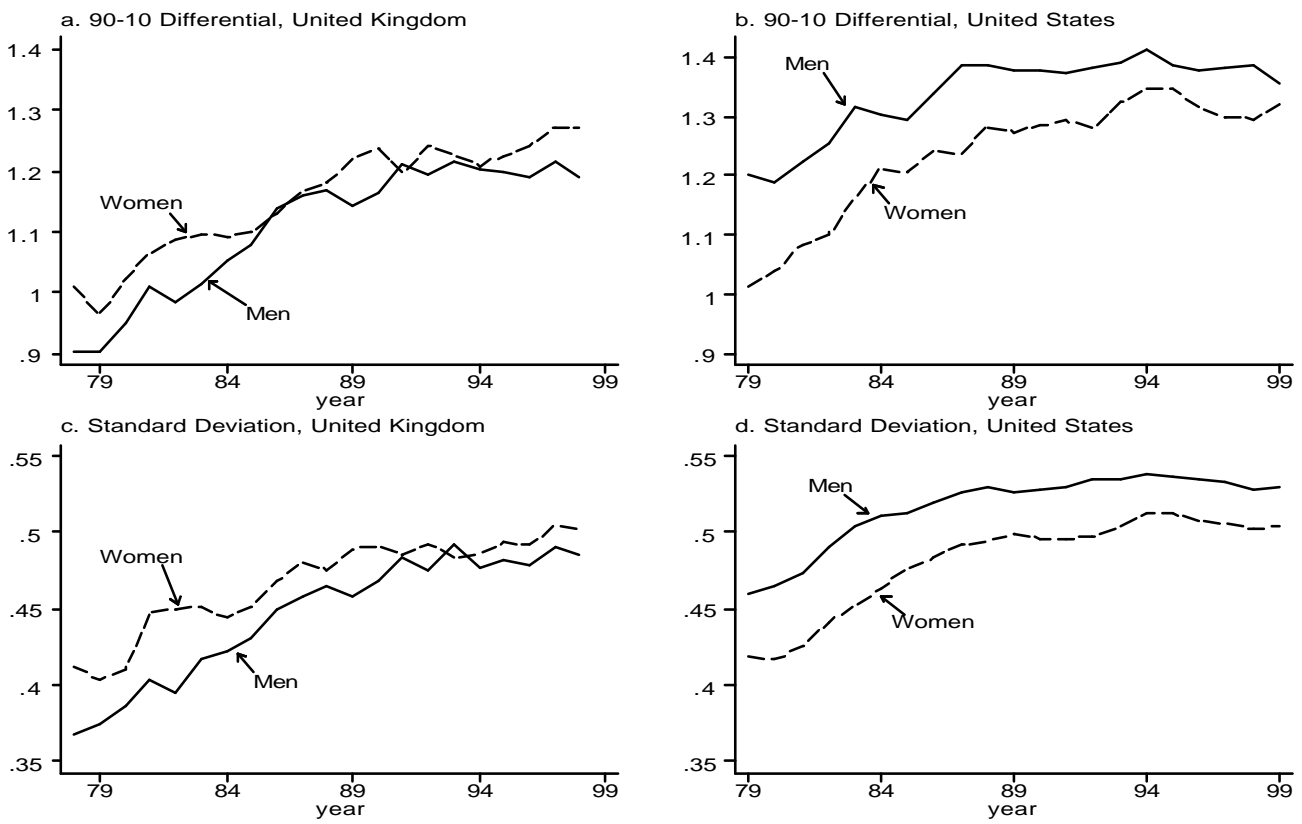

Figure 2: Log Wage Inequality, U.K and U.S 


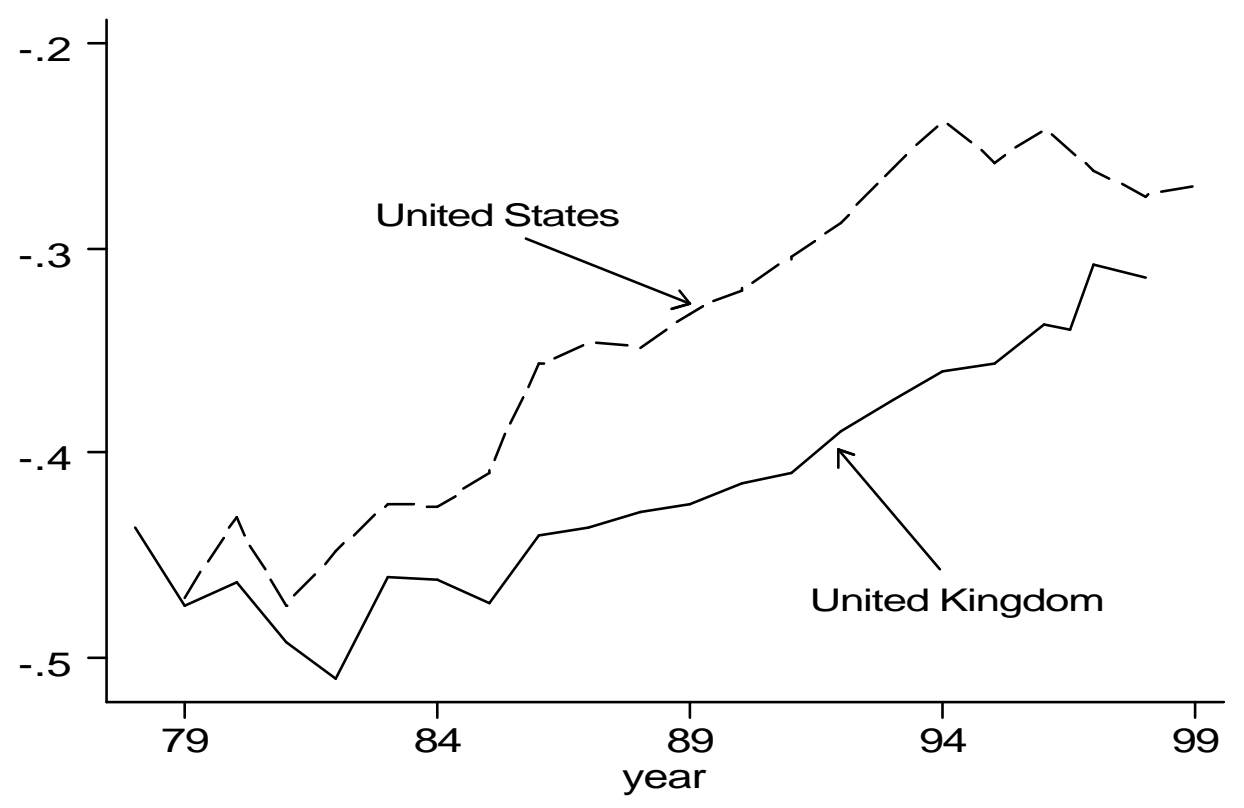

Figure 3: Gender Wage Gap, U.K. and U.S. 

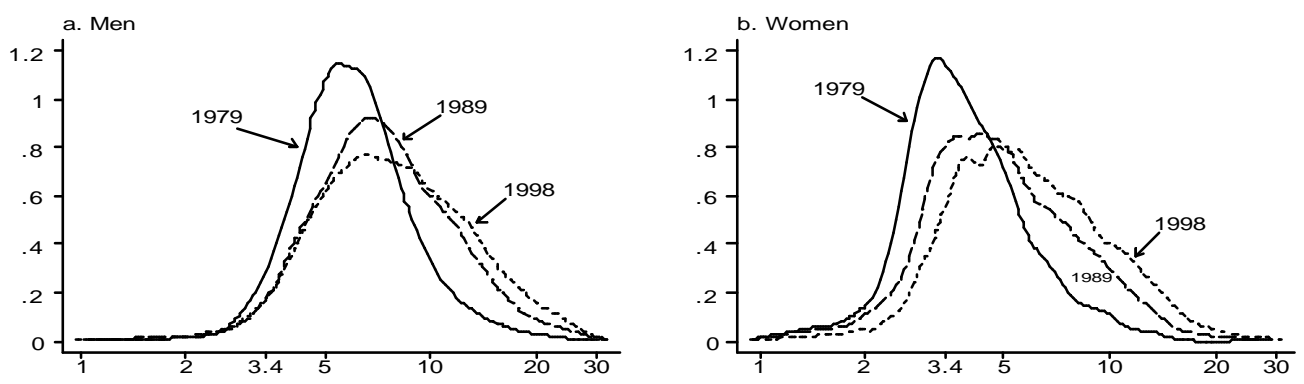

Figure 4: Density of Log Wages in the U.K.

in 1996 pounds
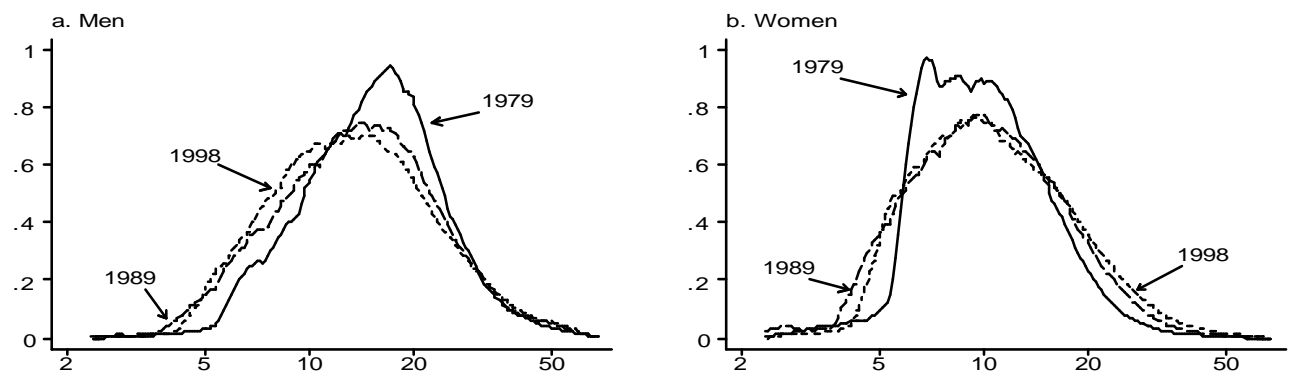

Figure 5: Density of Log Wages in the U.S.

in 1996 dollars 

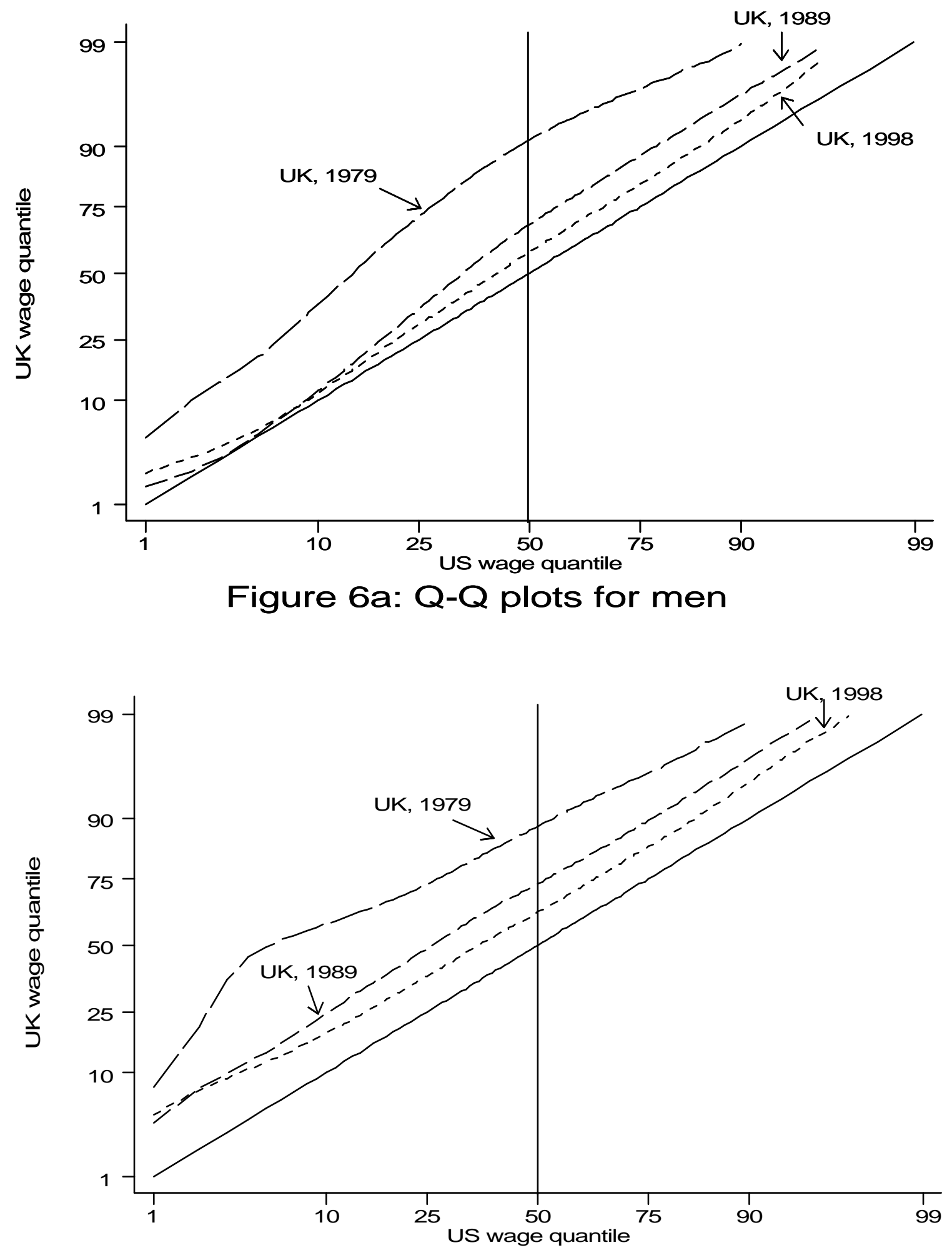

Figure 6b: $Q-Q$ plots for women 


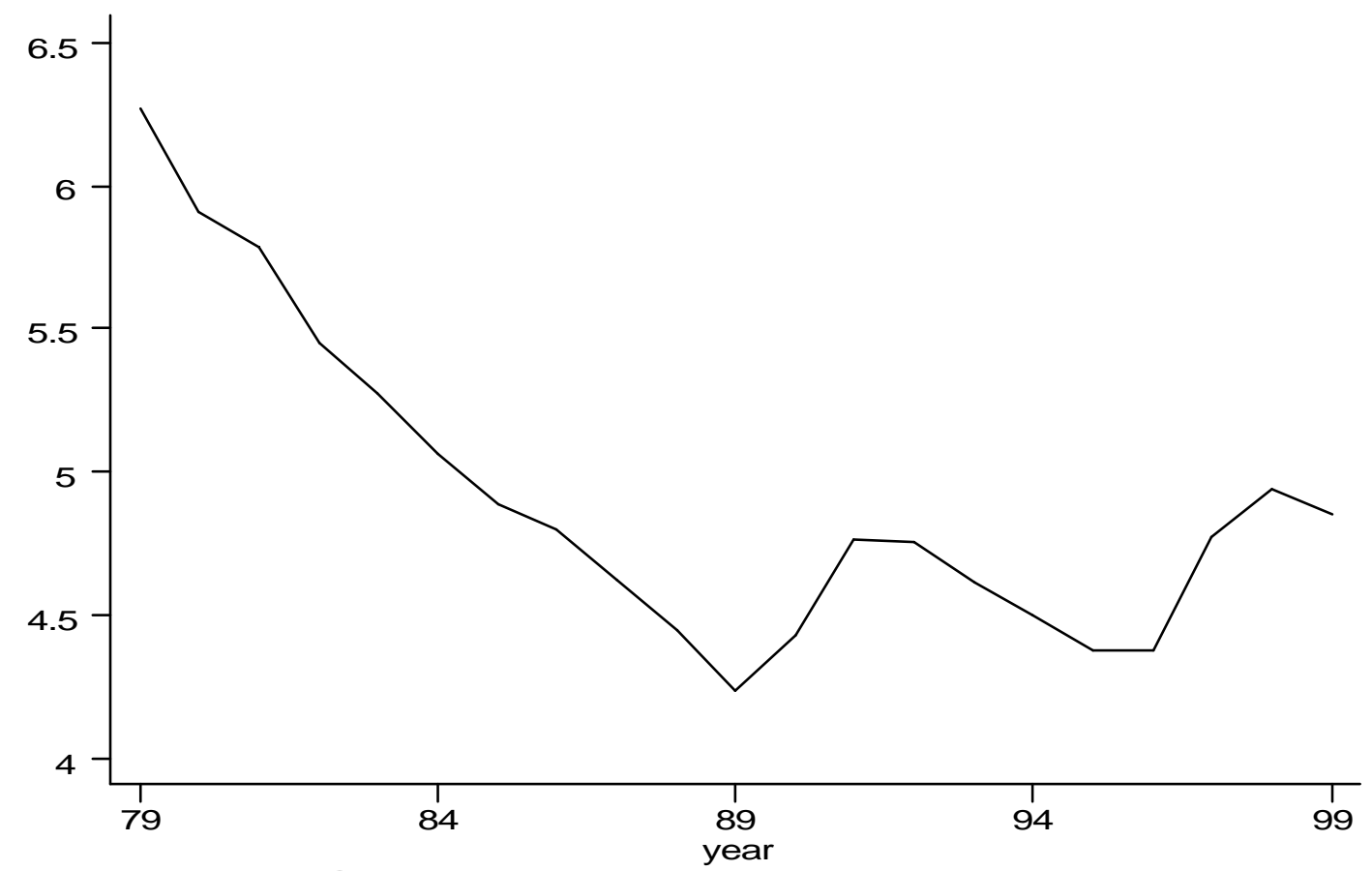

Figure 7: U.S. Federal Minimum Wage, 1996 dollars 


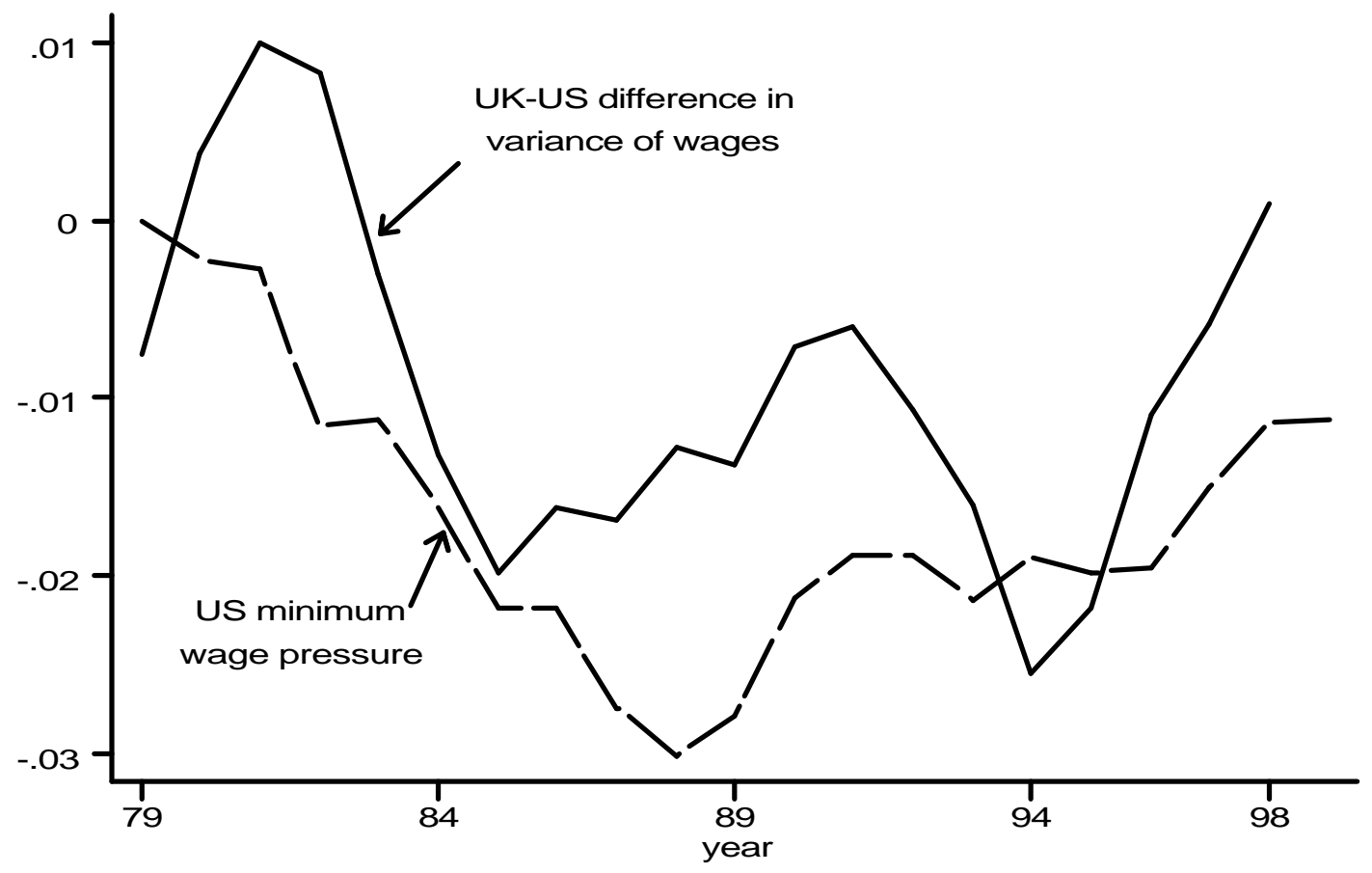

Figure 8: Minimum Wage and UK-US Female Variance Gap 


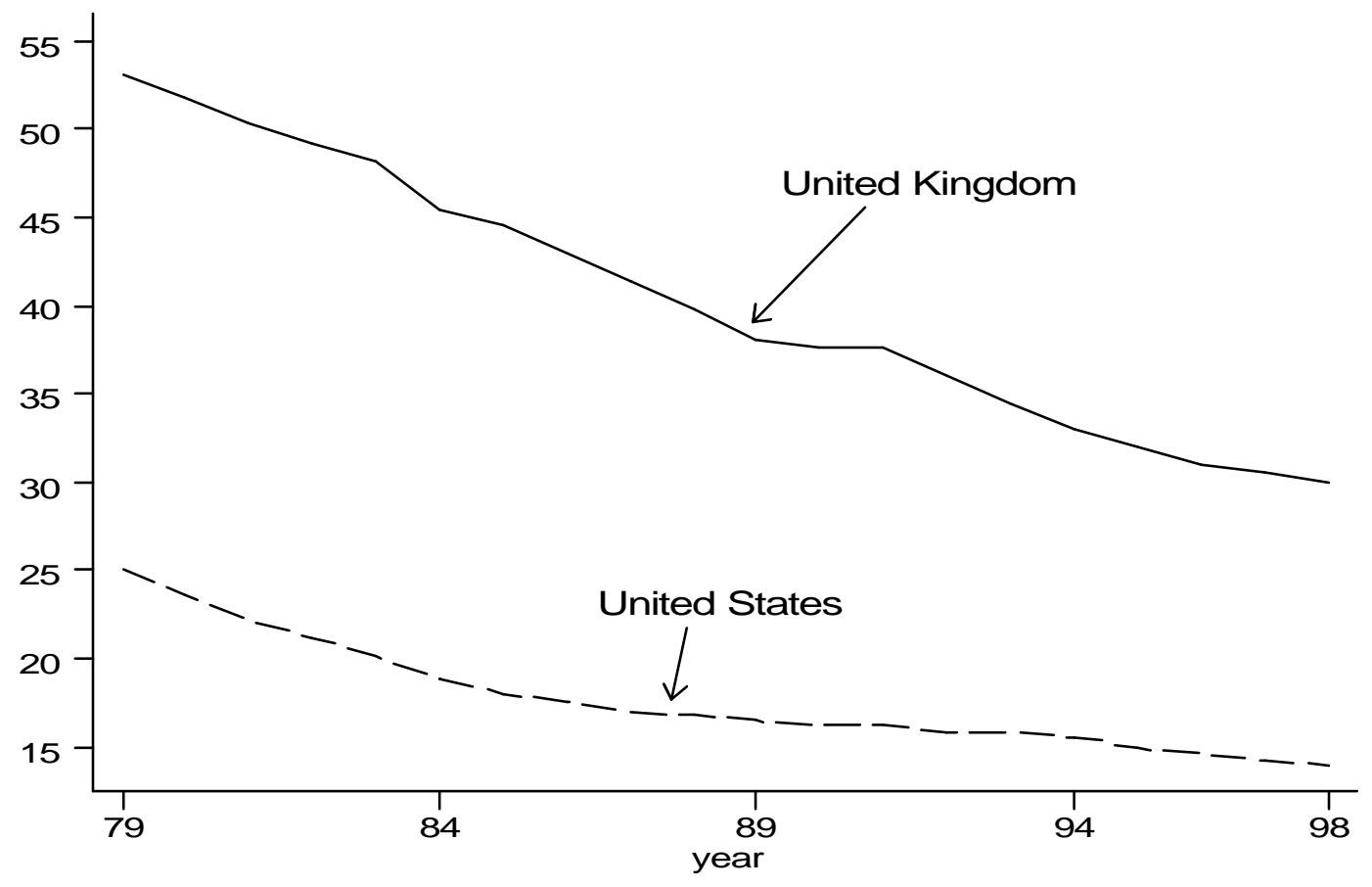

Figure 9: Union membership rate, U.K. and U.S. 


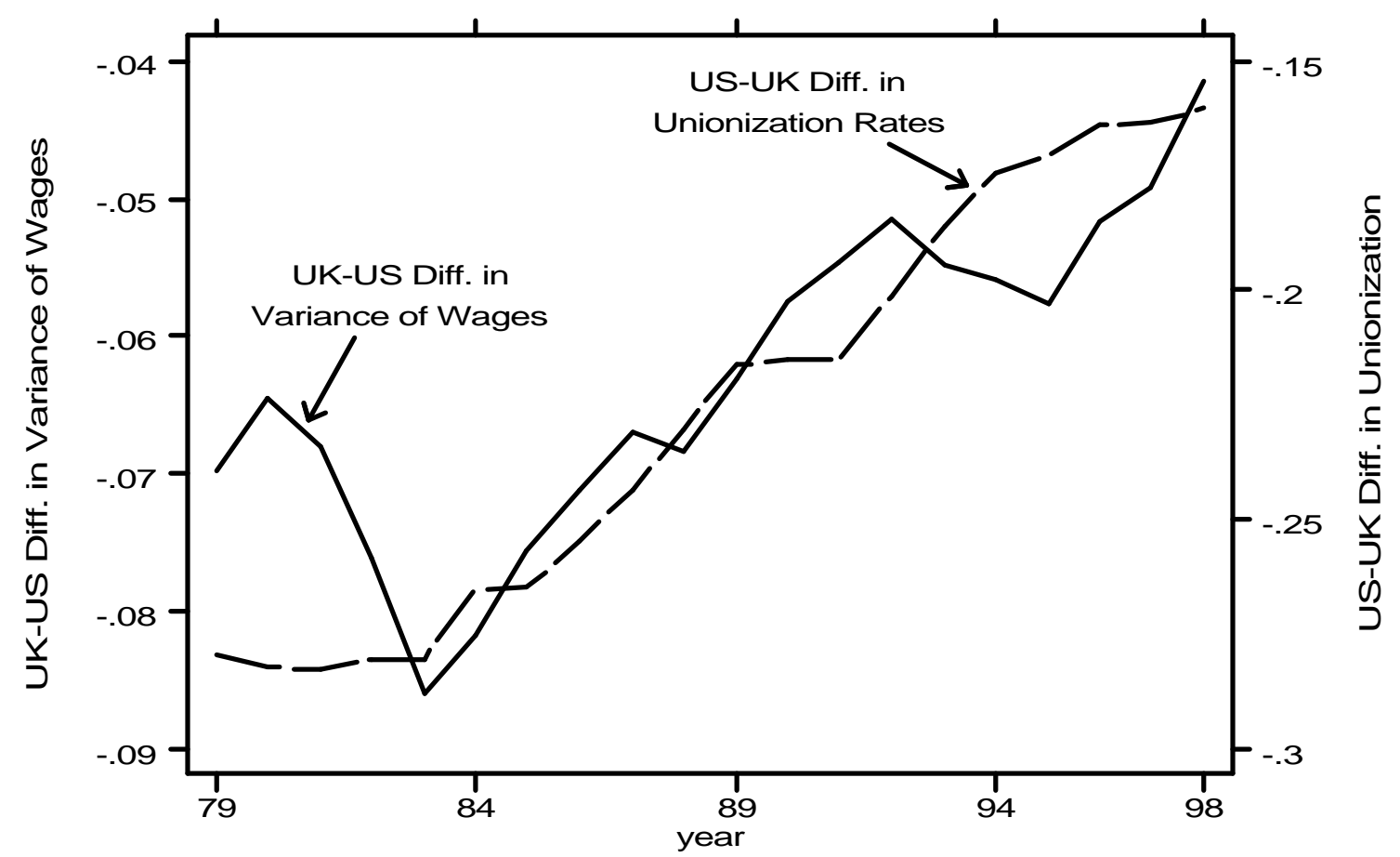

Figure 10: UK-US Male Variance Gap and Unionization 


\section{DATA APPENDIX}

\section{U.K. Data}

The most consistent source of information on the distribution of hourly wages in the United Kingdom is the Family Expenditure Survey (FES) that has collected detailed information on weekly earnings and weekly hours of work on a consistent basis since 1966. One limitation of the FES, however, is that it contains no information on educational achievement before 1978, and only limited information from 1978 on. ${ }^{38}$ An alternative data set that provides more detailed information on educational achievement is the General Household Survey (GHS) that has collected information on earnings and hours since $1974 .{ }^{39}$ Unfortunately, as hours are not measured in a consistent fashion over time, it is not possible to use the GHS to construct a consistent measure of hourly wage rates over the 1980s and 1990s.

Another limitation of the FES is that it does not contain direct information on the union status of workers. ${ }^{40}$ This information is available, however, in the 1983 GHS that also contains information on whether individuals work in the public or private sector. More recently, the Labour Force Survey (LFS) has been collecting detailed information on wages, union status, and public sector affiliation each year for the mid and late 1990s. The LFS is very similar to the U.S. Current Population Survey in terms of its purpose measuring labour market activity and unemployment in a timely fashion-and sample size. The sample sizes are also considerably larger in the LFS (around 15,000 wage and salary workers per quarter) than in the FES or the GHS (around 5,000 wage and salary workers per year).

In light of the strengths and weaknesses of the different data sets, we use a "multiple data set" approach for the United Kingdom. More precisely, we compute the basic trends in wage inequality using the FES for 1978 to 1996 supplemented with the

\footnotetext{
${ }^{38}$ The FES provides limited information on school leaving age but no information on the highest educational degree obtained. Gosling, Machin, and Meghir (2000) nevertheless argue that the limited information about educational achievement available in the FES is, nevertheless, sufficient for capturing main trends in relative wages by education level.

${ }^{39}$ See Gosling, Machin and Meghir (2000) for more detail on the strengths and weaknesses of the GHS and FES.

${ }^{40}$ The FES does contain a variable indicating whether the respondent has deductions from his or her earnings for the payment of union dues. Although this is highly correlated with the union status of workers at one point in time, changes in the way union members pay their fees over the 1980s and 1990s has meant that it is not a good measure of changes over time
} 
autumn LFS for 1997 and 1998. We analyse the effect of unionisation and public sector affiliation on wage inequality using the 1983 GHS and the 1998 LFS. Note that we have adjusted the 1997 and 1998 measures of wage dispersion reported in Table 1 and Figures 1 and 2 to ensure that there are no discrepancies in the series because of data differences. More precisely, we compute adjustment factors (that we apply to the 1997 and 1998 LFS) that are such that measures of wage dispersion in the 1996 LFS and 1996 FES are identical.

Following the existing literature on inequality in the U.K., we also limit the analysis to workers age 23 to 59. Real wages are obtained by deflating nominal wages with the Consumption Price Index (Retail Price Index). To limit the effect of outliers, we only keep observations with an hourly wage rate between one and thirty pounds (in 1996 pounds). Note that throughout the 1978 to 1998 period, there is always less than one percent of observations with wages that are either larger than 30 pounds, or smaller than a pound. As discussed below, one additional reason for trimming the wage data above 30 pounds is to make the U.K. data more comparable with the U.S. data for which weekly earnings are top-coded.

\section{U.S. Data}

Since 1979, the U.S. Census Bureau has been collecting data on weekly hours, weekly earnings, and hourly earnings (for workers paid by the hour) for all workers in the "outgoing rotation group" of the Current Population Survey (CPS). Beginning in 1983, the outgoing rotation groups supplement of the CPS also asks about the union status of workers. Since the questions about wages, hours, and union status are asked at every month, the resulting merged outgoing rotation group (MORG) files of the CPS provide very large samples (around 150,000 workers per year) of wage and salary workers from 1979 to 1999 . Our U.S. analysis entirely relies on this data source.

Throughout the 1979 to 1999 period, workers paid by the hour were asked their hourly rate of pay. We use this variable, which is collected in a consistent fashion over time, as our measure of the hourly wage rate for these workers. The MORG files of the CPS also provide information on usual weekly earnings for all workers. For workers not 
paid by the hour, we use average hourly earnings (weekly earnings divided by weekly hours) as our measure of the wage rate.

Note, however, that weekly earnings are not measured in a consistent fashion over time. From 1979 to 1993, this variable was collected by asking directly individuals about their earnings on a weekly basis. From 1994 to 1999, individuals had the option of reporting their usual earnings on the base period of their choice (weekly, bi-weekly, monthly, or annually). Weekly earnings are then obtained by normalized the earnings reported by workers to a weekly basis. The available evidence does not suggest, however, that this change in the way earnings are collected had a significant impact on the distribution of wages. ${ }^{41}$

A potentially more important problem is that weekly earnings are top-coded at different values for different periods throughout the sample period. Before 1988, weekly earnings were topcoded at 999 dollars. The topcode was later increased to 1923 dollars in 1988 and 2884 dollars in 1998. In real terms, the topcode was more than twice as small in 1988 as in 1998. Consequently, a much larger fraction of workers had their earnings topcoded in 1988 than in 1998.

We adjust for topcoding by using the 1998 distribution of weekly earnings to impute earnings in the other years where the topcode is lower. Let $\mathrm{tc}_{\mathrm{t}}$ represent the earnings topcode in year $t$ in real terms, and $f(y)$ represent the density of weekly earnings (not topcoded) in that year. Consider the assumption that the earnings distribution in year t between the topcode and the higher year 1998 topcode is that same as in 1998, i.e. that $\mathrm{f}_{\mathrm{t}}\left(\mathrm{y} \mid \mathrm{tc}_{\mathrm{t}}<\mathrm{y}<\mathrm{tc}_{98}\right)=\mathrm{f}_{98}\left(\mathrm{y} \mid \mathrm{tc}_{\mathrm{t}}<\mathrm{y}<\mathrm{tc}_{98}\right)$. Under this assumption, the empirical distribution of earnings between $t_{t}$ and $t_{98}$ in 1998 can be used to impute earnings in year $t$. While it is common to impute a fixed value of earnings to all topcoded observations, doing so removes all the earnings variability over the topcode, which in turn understates the extent of overall wage variability measured using the standard deviation or other distributional

\footnotetext{
${ }^{41}$ Once the data has been trimmed for outliers and adjusted for topcoding, there is no evidence of an unusual jump in wage inequality between 1993 and 1994.
} 
measures. ${ }^{42}$ In practical terms, we stochastically impute earnings above the topcode by drawing at random from the empirical 1998 distribution between $\mathrm{tc}_{\mathrm{t}}$ and $\mathrm{tc}_{98}{ }^{43}$

One final adjustment we make is to trim observations with wages above $\$ 50$ dollars and below \$2 in dollars of 1989 (approximately \$2.5 and \$63 in 1996 dollars). Once topcoding has been adjusted for, less than one percent of observations fall outside of this range in any single year. We noticed that when wage observations are not trimmed, there is an unusual jump in most measures of wage inequality between 1993 and 1994. We conjecture that the new survey instrument used to collect weekly wages since 1994 may have introduced more measurement error than before 1994.

For the sake of comparability with the United Kingdom, all wages measures presented in the paper are deflated using the Consumer Price Index. Other studies have used a the GDP deflator for personal consumption expenditures to deflate wages in part because of concerns that changes in the CPI are biased up, which understates real wage growth. Unless the bias is different in the United States and the United Kingdom, however, this should not affect comparisons of real wage growth between the two countries. All the U.S. wage statistics reported in the paper are also weighted using the CPS earnings weights. ${ }^{44}$

Questions about educational achievement were changed substantially in the early 1990s. Until 1991, the CPS used to ask about the highest grade (or years of schooling) completed. Starting in 1992, the CPS moved to questions about the highest degree. To keep a relatively consistent measure of education over time, we measure education using five categories (high school dropout, high school graduate, some post-secondary degree below a university bachelor's degree, university bachelor's degree, and post-graduate degrees).

\footnotetext{
${ }^{42}$ In terms of between and within-group variation of earnings above and below the topcode, standard imputation amount to assuming there is no within-group variation above the topcode.

43 A similar approach is used by DiNardo, Fortin, and Lemieux (1996) who use a reweighting procedure to allocate values above the topcode. They also allow for the fact that the distribution of earnings depends on standard characteristics such as age, education and gender.

${ }^{44}$ By contrast, the U.K. data are unweighted since sample weights are not available in the FES and the GHS. Sample weights are available in the LFS but since weighting make very little difference, we use unweighted data for this survey as well to be consistent with the FES and the GHS.
} 
Appendix Table 1: Ordinary Least Squares Estimates of the Union Wage Gap in the United Kingdom and the United States

\begin{tabular}{|c|c|c|c|c|c|c|}
\hline & \multicolumn{3}{|c|}{ United Kingdom } & \multicolumn{3}{|c|}{ United States } \\
\hline & \multicolumn{3}{|c|}{ Gap Adjusted For } & \multirow[b]{2}{*}{$\begin{array}{c}\text { Unadjusted } \\
\text { Gap } \\
(4)\end{array}$} & \multicolumn{2}{|c|}{ Gap Adjusted For } \\
\hline & $\begin{array}{c}\text { Unadjusted } \\
\text { Gap } \\
(1)\end{array}$ & $\begin{array}{c}\text { Human } \\
\text { Capital } \\
\text { (2) }\end{array}$ & $\begin{array}{c}\text { H.C. and } \\
\text { job. char } \\
\text { (3) }\end{array}$ & & $\begin{array}{c}\text { Human } \\
\text { Capital } \\
(5)\end{array}$ & $\begin{array}{c}\text { H.C. and } \\
\text { job. Char } \\
\text { (6) }\end{array}$ \\
\hline \multicolumn{7}{|l|}{$\mathrm{MEN}$} \\
\hline \multirow[t]{2}{*}{1983} & 0.094 & 0.124 & 0.087 & 0.150 & 0.162 & 0.173 \\
\hline & & $(0.012)$ & $(0.014)$ & & $(0.004)$ & $(0.004)$ \\
\hline \multirow[t]{2}{*}{1998} & 0.089 & 0.083 & 0.064 & 0.138 & 0.118 & 0.150 \\
\hline & & $(0.010)$ & $(0.011)$ & & $(0.005)$ & $(0.005)$ \\
\hline \multicolumn{7}{|l|}{ WOMEN } \\
\hline \multirow[t]{2}{*}{1983} & 0.255 & 0.184 & 0.091 & 0.238 & 0.195 & 0.177 \\
\hline & & $(0.013)$ & $(0.013)$ & & $(0.004)$ & $(0.004)$ \\
\hline \multirow[t]{2}{*}{1998} & 0.238 & 0.210 & 0.102 & 0.242 & 0.122 & 0.152 \\
\hline & & $(0.010)$ & $(0.010)$ & & $(0.005)$ & $(0.005)$ \\
\hline
\end{tabular}

Note: Standard errors in parentheses. Dependent variable is the log of hourly wages. Sample used in the estimation include wage and salary workers age 23 to 59 earning between 1 and 30 pounds per hour (1996 pounds) in the United Kingdom, and between 2.5 and 63 dollars an hour (1996 dollars) in the United States. U.S. data are from the outgoing rotation group files of the Current Population Survey. 1983 U.K. data are from the General Household Survey; 1998 U.K. data are from the Fall Labour Force Survey. Workers are divided between the "union" and "non-union" sectors on the basis of their self-reported membership to a trade union. The "human capital" controls used in columns 2, 3, 5, and 6 include education categories dummies ( 5 in the United States, 7 in the United Kingdom), region dummies (10 regions and London in the United Kingdom, 9 regions and SMSA status in the United States) a quartic in age, marital status, and dummy variables for nonwhites (U.S. only) and veteran status (U.S. men only). "Job characteristics" controls in column 3 include 9 industry dummies, 12 occupation dummies, a dummy variable for public sector affiliation, and dummy variables for firm size and seniority. Job characteristics controls in column 6 include 46 industry dummies and 45 occupation dummies. 

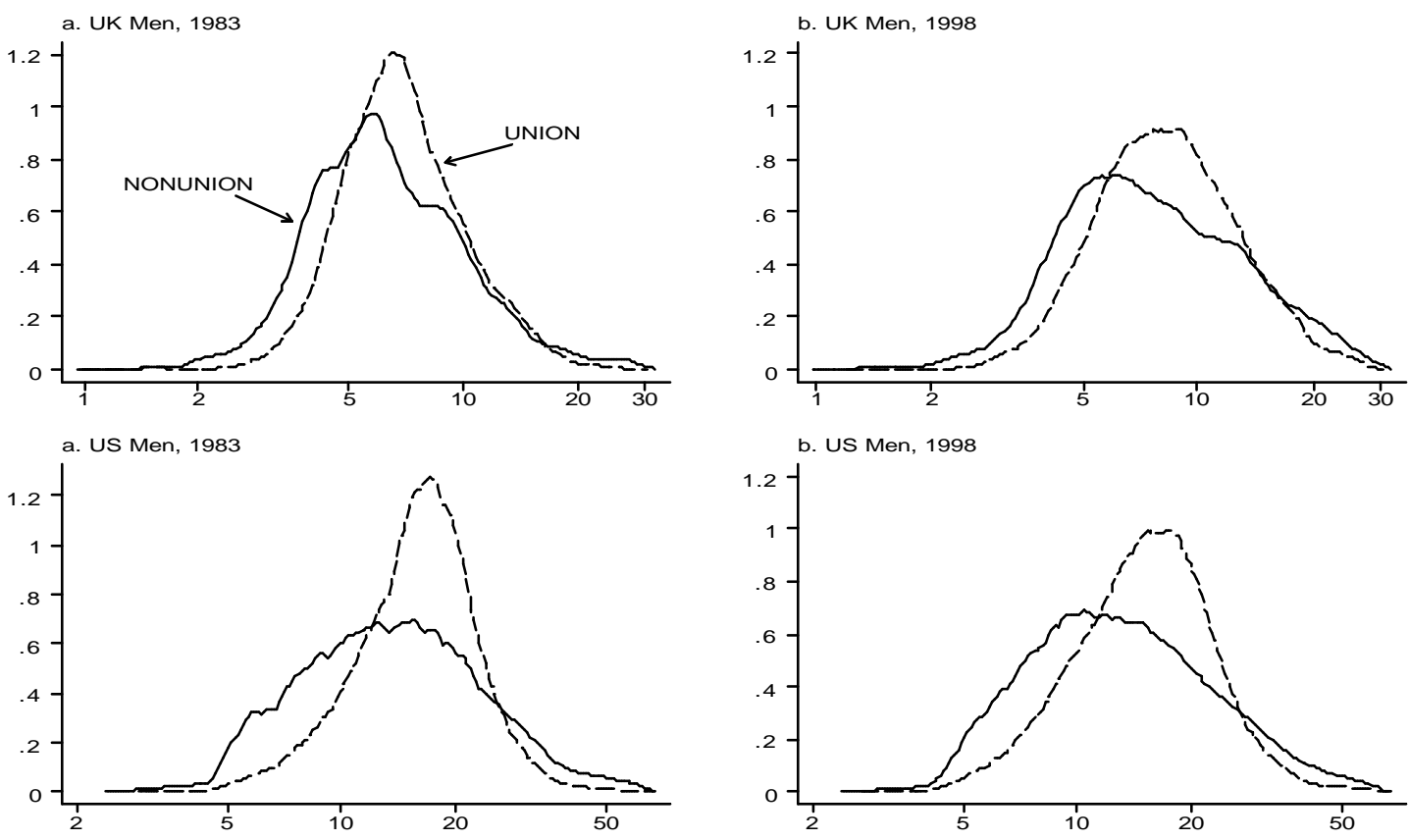

Appendix Figure 1: Union and Nonunion Wage Densities

U.K. [1996 pounds] and U.S. [1996 dollars] 